\title{
An analytical view of Students Interaction with E- Learning Environment ( Blackboard) at King Saud University. ${ }^{(*)}$
}

\section{Ibtesam Al-Nahed Hania Al-Shanawani}

\section{Abstract}

The purpose of this study was to examine students' level of interaction with e-learning environment at King Saud University. The present study dealt with interaction as represented in learners' attitudes, satisfaction and collaborative learning. Participants were 19 undergraduate female students who took e-learning format courses at college of Education , King Saud university. Data was collected using two tools: the first was face- to- face interview, the second tool was The Collaborative Learning and Satisfaction (CLS) Questionnaire. Analysis of qualitative data indicated that relationship between interaction and e-learning environment were not significant. But, the general correlation among the four variables of interaction (students' attitudes toward e-learning environment , its use as a learning style, their satisfaction and collaborative learning) is strong. Interview data revealed that students prefer the blackboard system as it's an easy system for communicating information and sending assignments . But, still this system faces problems related to some online 


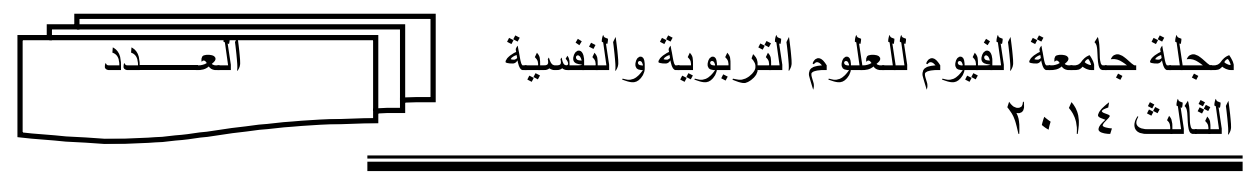

technical problems and low experience of some learners of using the site and the internet.

\section{Introduction}

The rapid development in information-communication technology including the web technology has brought a big impact in education world. Today, people are talking about elearning, cyber-learning, long-life learning, virtual learning and a few more terms have been used to describe a new way of learning. These terms are used to serve a same goal that is to provide the possibility of open and lifelong education without temporal or spatial constraint. Education in Saudi public universities is based on the traditional didactic, lecture-based classroom with a few programs implementing web-based distance learning (MCIT, 2007; Ali, Sait, \& Al-Tawil, 2003). Due to the recent emergence of blended learning in Saudi higher education, there is an urgent need to investigate students' interaction and satisfaction with blended learning system. The capacity of universities and colleges in Saudi Arabia is limited compared with the rapid growth of students applying for college education (Alebaikan and Troudi,2010b). To tackle this problem, the Ministry of Higher Education endeavors to integrate web based instruction with traditional instruction in universities.

Graham $(2006,3)$ points out that the essence of blended learning is the combination of face-to-face instruction and computer-mediated instruction. The goal of blended learning 


\section{An analytical view of Students Interaction Ibtesam Al-Nahed Hania Al-Shanawani}

should be to unite the best features of in class teaching with the best features of online learning, to promote active, selfdirected learning opportunities for students (Garnham \& Kaleta, 2002).

\section{Theoretical Background and Literature Review:}

\subsection{E-Learning Environment:}

E-learning is the most recent evolution of distance learning - a learning situation where instructors and learners are separated by distance, time, or both (Raab, Ellis, \& Abdon, 2002). E-learning uses network technologies to create, foster, deliver, and facilitate learning, anytime and anywhere.

\section{The major functions of e-learning:}

Liaw (2008) outlined major functions of the Blackboard as an e-leaning system including: blackboard homepage, teaching/ learning materials, discussion board, quiz, homework assignment, and link. N Furthermore, Capper (2001) listed the e-learning benefits as: any time, any place, asynchronous interaction, group collaboration and new educational approaches.

Liaw and Huang (2007) suggested that four elements should be considered when developing e-learning environments: environmental characteristics, environmental satisfaction, learning activities, and learners' characteristics. 


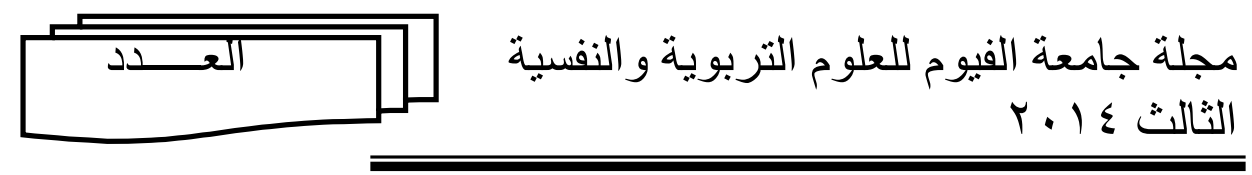

\subsection{Blended learning:}

Blended learning has been referred to as the "third generation"' (Phipps \& Merisotis, 1999, p. 26) of distance education systems. The American Society for Training and Development identified blended learning as one of the top 10 trends to emerge in the knowledge delivery industry. It's characterized as maximizing the best advantages of face-toface learning and multiple technologies to deliver learning ( So and Brush,2008). Vesisenaho et. al. (2010) pointed out that this means traditional face-to-face teaching or lecturing with additional materials and learning assignments online, using different learning management systems. Al-Jarf (2005) conducted a study in a Saudi Arabian university to find out whether or not integration of online learning with face-to-face grammar instruction significantly improves English-as-aforeign-language freshman college students' achievements and attitudes. The study concluded that in learning environments where technology is unavailable to English-as-a-foreignlanguage students and instructors, use of an online course from home as a supplement to in-class techniques helps motivate and enhance English-as-a-foreign-language students' learning and mastery of English grammar.

\subsubsection{Definition:}

So and Brush (2008) defined blended learning as any combination of learning delivery methods, including most 


\section{An analytical view of Students Interaction Ibtesam Al-Nahed Hania Al-Shanawani}

often face-to-face instruction with asynchronous and/or synchronous computer technologies.

Blended e-Education (BeE) refers to an integrated environment, which combines the advantages of e-Learning and traditional classroom teaching (Graham, 2006).

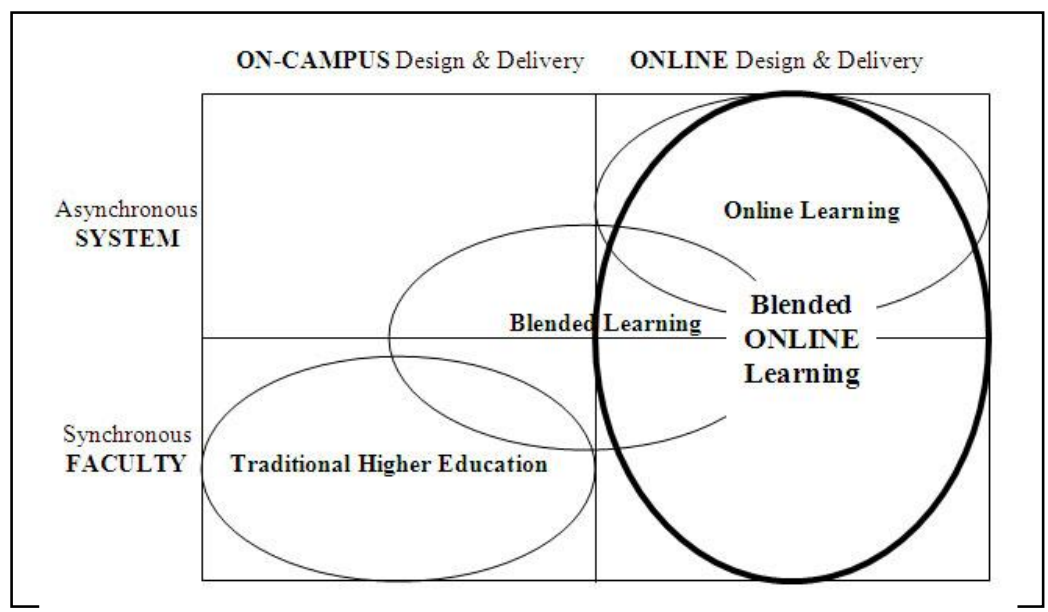

Figure (1): Blended online learning environment from Vaughan (2010)

The three most commonly mentioned definitions documented by Graham, Allen, and Ure (2003) are:

- combining instructional modalities (or delivery media) (Bersin \&Associates, 2003; Orey , 2002a, 2002b; Singh \& Reed, 2001; Thomson, 2002)

- combining instructional methods (Driscoll, 2002; House, 2002; Rossett, 2002) 
- combining online and face-to-face instruction (Reay, 2001; Rooney, 2003; Sands, 2002; Ward \& LaBranche, 2003; Young, 2002)

\subsubsection{Rationale:}

Online learning environments have been criticized for its lack of human interaction and, for this reason, there has been an increasing movement toward blended learning approaches where students can have opportunities for both online and offline interaction with their instructors and classmates (Allen \& Seaman,2003). Thus, BL helps to overcome the limitations of face-to-face and online education. blended learning not only offers more choices but also is more effective. The purpose is to use different online environments, and tools of social software, actively during the face-to-face session in order to capture students' thinking and their work (Vesisenaho et. al. ,2010).

In order to improve the quality of learning, some important elements have to be managed, such as technology, the structure of the course, the instructor, technical support, assignments student engagement and learning flexibility (Alobeikan \& Troudi,2010b). Blended learning has been implemented with various designs and has shown a considerable positive effect on the learning process.

Osguthorpe and Graham (2003) identified six reasons why one might chose to design or use a blended learning 


\section{An analytical view of Students Interaction Ibtesam Al-Nahed Hania Al-Shanawani}

system: (1) pedagogical richness, (2) access to knowledge, (3) social interaction, (4) personal agency, (5) cost effectiveness, and (6) ease of revision. In the BL literature, the most common reason provided is that BL combines "the best of both worlds"

Harvard Business School faculty DeLacey and Leonard (2002) reported that students not only learned more when online sessions were added to traditional courses, but student interaction and satisfaction improved as well.

So and Brush (2008) added that , blended learning environments, increases students' self-motivation and selfmanagement because there is less in-class time and more emphasis on self-regulated learning.

Kim (2012)_explored and described different viewpoints on blended e-Education by using $Q$ methodology to identify students' perspectives and classify them into perceptional types. It is also designed to examine possible relationships among learner's perceptional type, characteristics (i.e., academic self-efficacy, interest in blended e-Education, and extraversion) and academic achievement levels. Fifty undergraduate students taking blended e-education courses at a Korean university were chosen as participants in this study. As a result of the study, four types of learners were identified and given the following descriptive labels: (I) e-Education Interested Type, (II) Traditional Lecture Friendly Type, (III) Social Interactionist Type, and (IV) Yes-But Mixed Type. 


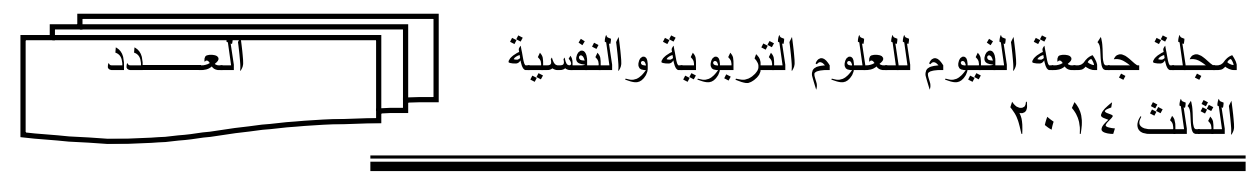

Further, it was found that those who have either higher academic self-efficacy or extraversion achieved higher academic achievement. It is also shown that female students in general have less interest in blended e-Education. Implications of these results are discussed in the context of blended eEducation course design.

Alebaikana \& Troudi (2010) investigated the effectiveness of online discussion use in blended courses at Saudi Arabian Universities. The study presented issues that have to be considered before employing online discussion in blended courses. Using qualitative research, a rigorous data collection procedure was developed by employing multiple data collection methods that included observations, focus groups and in-depth interviews. The participants were female undergraduate students and instructors of different courses. The results highlighted the issues to be considered in utilizing efficient online discussion, which are: e-pedagogy, eplagiarism, infrastructure, Learning Management System tools, and demands on time.

According to Garrison and Kanuka (2004), the simplest model of blended learning "is the thoughtful integration of classroom face-to-face learning experiences with online learning experiences" aiming at taking advantage of a synchronous face-to-face situation and the asynchronous, text-based Internet. 


\section{An analytical view of Students Interaction Ibtesam Al-Nahed Hania Al-Shanawani}

Zhang et al. (2006) listed some of the benefits of e-learning as follows:

- It provides time and location flexibility;

- It results in cost and time savings for educational institutions;

- It fosters self-directed and self-paced learning by enabling learner-centered activities;

- It creates a collaborative learning environment by linking each learner with physically dispersed experts and peers;

- It allows unlimited access to electronic learning material; and It allows knowledge to be updated and maintained in a more timely and efficient manner.

For the effective implementation of this blended approach, educators should address the following desiderata:

(1) pedagogical richness (improving student learning),

(2) increasing accessibility to information,

(3) social interaction,

(4) personal agency (offering to students a means for directing their own learning),

(5) cost effectiveness

(6) ease of revising a blended system (Osguthorpe \& Graham, 2003). 


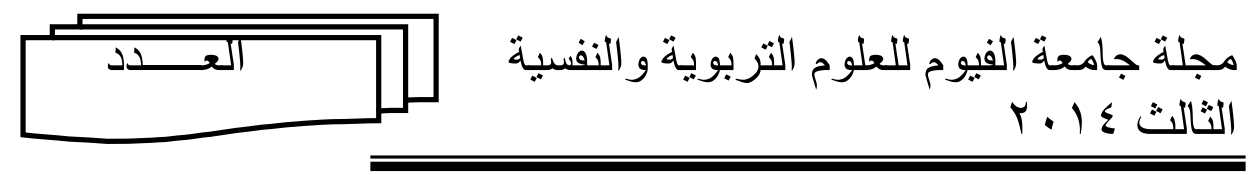

Graham (2004) outlines six major issues that are relevant to designing blended learning systems. The issues are: (1) the role of live interaction, (2) the role of learner choice and self-regulation, (3) models for support and training, (4) finding balance between innovation and production, (5) cultural adaptation, and (6) dealing with the digital divide.

\subsubsection{Benefits:}

Smyth (2010) listed some of the benefits of blended learning as follows:

- blended learning provided them with a unique flexible learning experience, because they could access and engage with their educational program from anywhere and at any time.

- the approach provides autonomy in learning

- It enables problem solving

The effect of blended learning on students' computer and mathematics attitudes in a Saudi Arabian university was investigated by Yushau (2006). Two modes of learning implemented during the experiment were face-to-face learning, three times a week, and online learning consisting of a weekly computer laboratory session with availability of online learning resources in the intranet and Internet to the students. The results indicated that the students have positive attitudes towards mathematics and computer.

Lancaster et al. (2011) conducted a study to assess the impact of a novel teaching model on student learning and perception. A hybrid teaching model was implemented within 


\section{An analytical view of Students Interaction Ibtesam Al-Nahed Hania Al-Shanawani}

the second professional year of the Doctor of Pharmacy curriculum at Northeastern University in Boston, Massachusetts. This Institutional Review Board-approved study enrolled 97 students who accessed online materials in place of traditional lectures over a total of six lectures and had that information re-enforced via in-class active learning. All student quiz scores were compared using a paired $t$-test. A post survey was sent to all students to capture their attitudes and use of this teaching model. Results proved that students performed statistically significantly higher on quizzes and examinations when using this hybrid teaching model. Student attitudes toward this teaching model were mixed, largely because of perceived increases in their (or student) workload. This study demonstrated that using technology, such as podcasts and electronic lecture delivery enhances learning and bridges gaps with this more technologically advanced generation of students.

\subsubsection{Challenges :}

- the approach could be isolating as the opportunity to socially interact is limited.

- Maintaining a sense of community is challenging

- on-line component is invasive on students' everyday life, as there is no differentiation between college and home time

- $\mathrm{BL}$ is overwhelming and tiring experience.

- the internet connectivity is an issue. 


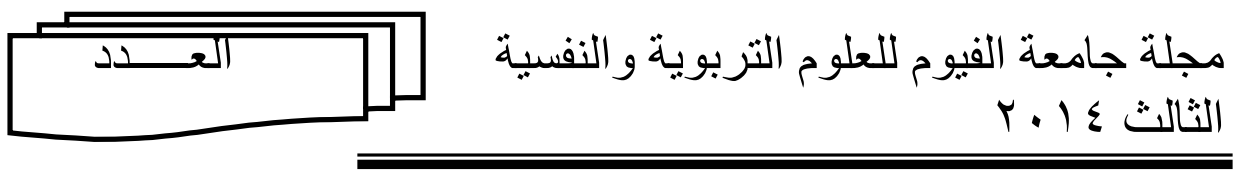

\subsection{Interaction in blended learning environment:}

Interaction can be defined as a reciprocal communication process between human and human or between human and non-human (e.g., human-computer interaction) (So and Brush,2008).

Dönmez et al. (2010) pointed out to several published taxonomies (Moore, 1989; Hillman et al., 1994; Carlson and Repman, 1999; Hannafin, 1989; Northrup, 2001; Bonk and Reynolds, 1997; Harris, 1994; Bonk \& King 1998; cited in Hirumi, 2006) which give educators insight into nature and range of interactions that may occur in e-learning. Hirumi (2006) discusses published elearning interaction taxonomies over four dimensions:

- Communication-based taxonomies specify sender and receiver of the interaction. Among the basic interactions are student-student, student-teacher, student-content, student-interface interactions.

- Purpose-based taxonomies codify interactions based on purpose. These are actions taken by learner like: confirm, pace, inquire, navigate and elaborate.

- Activity-based taxonomies specify the level of type of interactivity experienced by learners. Literature suggests number of activities that may be designed to promote critical thinking, creative thinking and online cooperative learning.

- Tool-based taxonomies focus on the capabilities afforded by various technologies facilitating e-learning. 


\section{An analytical view of Students Interaction Ibtesam Al-Nahed Hania Al-Shanawani}

Among these technologies are e-mail, asynchronous messaging, remote access and delayed collaboration tools, real time brainstorming and conversation tools and real time multimedia and hypermedia collaboration tools.

Hirumi (2006) argues these taxonomies to be valuable but away from practice and proposes a framework positing three interrelated levels of interactions.

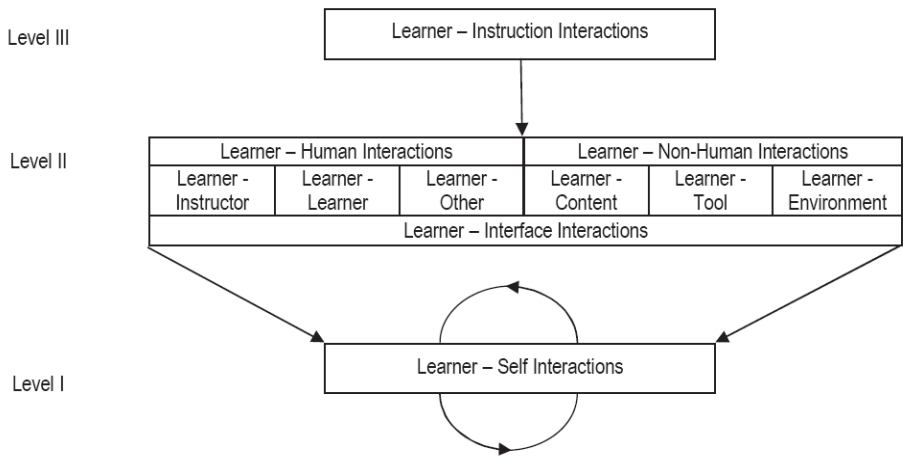

(Level I) consists of cognitive operations that constitute learning and the metacognitive processes that help individuals monitor and regulate learning.

(Level II ) interactions occur between the learner and the other human or non-human resources. Learner - Instruction interactions (Level III) are considered to be a meta-level that transcends and used to guide the design and sequencing of Level II interactions.

According to So and Brush (2008), there are three types of interaction: 


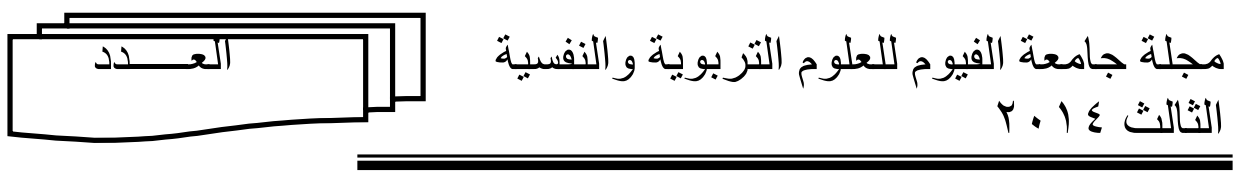

(a) learner-content interaction, (b) learner-instructor interaction, and (c) learner-learner interaction. The interaction between learner and content takes place when learners gain content knowledge through one or more forms of media such as tutorials, CD-ROMs, or web-based courses. The learner instructor interaction happens when an instructor delivers content knowledge, provides appropriate scaffolding, clarifies misunderstanding, and increases student motivation. Lastly, the learner-learner interaction occurs when learners in different geographical areas interact with each other to achieve a certain goal. The following figure shows the three types of interaction taken from (YUCEL,2006):

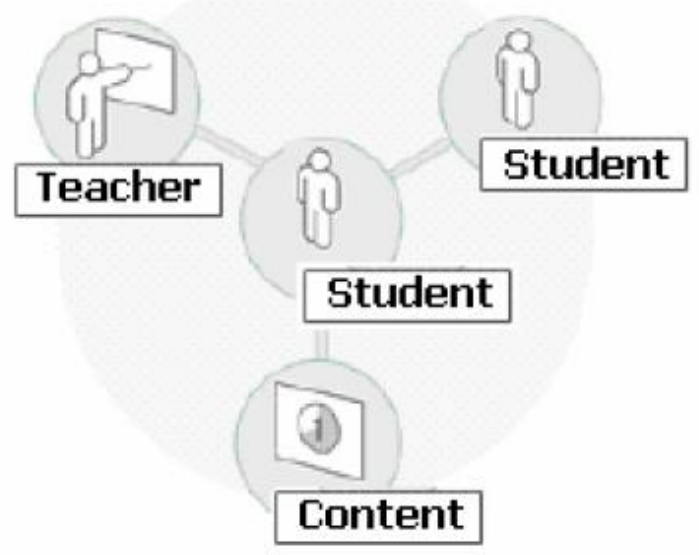

Figure: 2

Types of Interaction in Learning Environments

Hillman, Willis, and Gunawardena (1994) stressed that "the learner must interact with the technological medium 


\section{An analytical view of Students Interaction Ibtesam Al-Nahed Hania Al-Shanawani}

to interact with the content, instructor, or other learners" ( $\mathrm{p}$. 33), The aim of bringing in online environments is not just to provide extra materials or separate assignments but to add a new "layer" to the face-to-face teaching and learning situation (Vesisenaho et. al. ,2010). Learner interaction in elearning environments gives several clues about learner characteristics. Dönmez et al. (2010) presented their experiences regarding knowing about learners via learnerenvironment interaction. Learner interaction was employed in two studies. In first study reporting capabilities of an LMS was used. In second study an innovative LOGO environment was created from scratch and learner interaction was employed to keep track of learners' problem solving practices

Alebaikana Troudi (2006) asserted the important role of interaction in quality learning stating that "interaction is the key element and quality standard of a quality learning experience in higher education".

Zhang et al. ' s (2006) empirical study examined the influence of interactive video on learning outcome and learner satisfaction in e-learning environments. Four different settings were studied: three were e-learning environments-with interactive video, with non-interactive video, and without video. The fourth was the traditional classroom environment. Results of the experiment showed that the value of video for learning effectiveness was contingent upon the provision of interactivity. Students in the e-learning environment that 


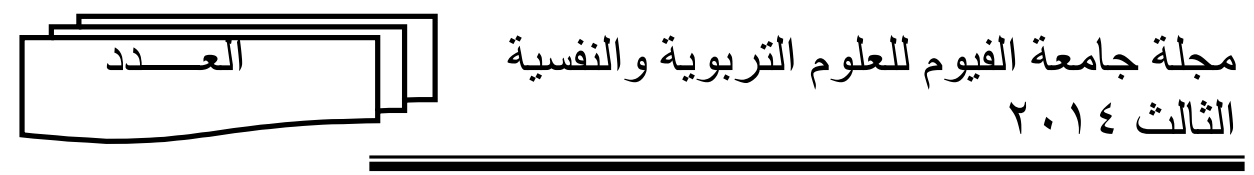

provided interactive video achieved significantly better learning performance and a higher level of learner satisfaction than those in other settings. However, students who used the elearning environment that provided non-interactive video did not improve either. The findings suggest that it may be important to integrate interactive instructional video into elearning systems.

\subsection{Collaborative learning:}

By collaboration, we mean "sharing experience", hence blended learning provides collaboration where students learn from the ideas and mistakes of others and share their experiences to create a rich knowledge resource(Alebaikana \&Troudia,2010) .Collaborative learning is a form of learner and learner interaction and it has been considered as an effective instructional method in both traditional and elearning settings (Bernard, Rubalcava, \& St-Pierre, 2000). Huang et al. (2012) pointed out that collaborative learning allows students to interact with others, which stimulates higher-order thinking skills in face-to-face learning settings . He added that the process of social and cognitive interactions with group members is the key to making successful completion happen in group collaboration.

Promoting collaboration among learners has been regarded as a challenging instructional strategy (So and Brush,2008). Some studies found that students who participated in online collaborative tasks expressed higher 


\section{An analytical view of Students Interaction Ibtesam Al-Nahed Hania Al-Shanawani}

levels of satisfaction with their learning process compared to students who didn't participate in online collaborative learning (Jung, Choi, Lim, \& Leem, 2002).

So and Brush, (2008 ) inferred that collaborative learning structures allowing more control and dialogue among learners could reduce transactional distance. When designed and applied appropriately in distance learning environments, collaborative learning strategies can provide learners with several advantages, such as opportunities to experience multiple perspectives of other distance learners from different backgrounds, and to develop critical thinking skills through the process of judging, valuing, supporting, or opposing different viewpoints (Hakkarainen, Lipponen, \& Jarvela, 2002; Stacey, 1999). Several studies utilized handheld devices and wireless connection in group collaboration to promote students' learning performance and increase knowledge (Liu \& Kao, 2007; Ogata \& Yano, 2004). It appears that blended learning methods are effective in facilitating the process of online collaborative learning (Carr-Chellman et al., 2000; Gabriel, 2004; Graham, Scarborough, \& Goodwin, 1999).

Face-to-face situations are important for successful virtual work. The participants who do not know each other will easily drop out of virtual work. Face-to-face situations make it easier to work collaboratively and help to create virtual interaction Lindfors (2010) 


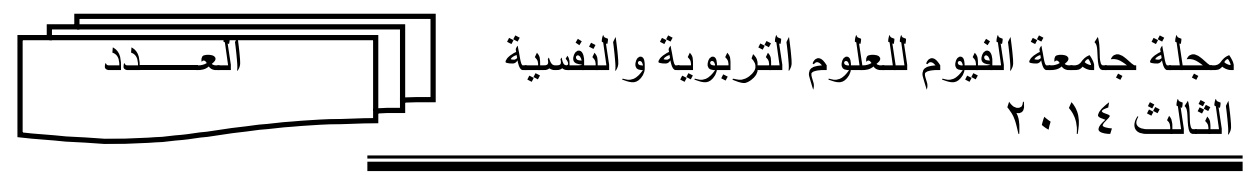

In the field of collaborative learning, Huang et al. (2012) conducted a study to evaluate the effectiveness of using procedural scaffoldings in fostering students' group discourse levels and learning outcomes in a paper-plus-smartphone collaborative learning context. All participants used built-in camera smartphones to learn new knowledge by scanning Quick Response (QR) codes, a type of two-dimensional barcode, embedded in paper-based learning materials in this study. Sixty undergraduate and graduate students enrolled at a four-year university in southern Taiwan participated in this study. Participants were randomly assigned into two different groups, using procedural scaffoldings learning and nonprocedural scaffoldings learning. The learning unit about the Long Tail, an important concept used in products sales, was the learning task that participants were expected to complete. During the experiment, pretest-posttest and the completed group worksheets were used to collect data. The researchers applied content analyses, chi-square test, t-test, and ANCOVA to answer research questions. The findings indicated that participants in the experimental group using procedural scaffoldings achieved better learning outcomes than their counterparts in the control group in terms of group discourse levels, group learning, and individual learning.

Vesisenaho (2010)'s paper examined the possibilities of mobile technologies and social software in the contexts of blended learning and collaborative learning theories. The paper also provided two concrete examples of how these possibilities 


\section{An analytical view of Students Interaction Ibtesam Al-Nahed Hania Al-Shanawani}

have been put into practice in higher education, namely teacher education. It provided ideas for the use of mobile technologies and social software in teaching and learning.

\subsection{Students' satisfaction with blended learning environment:}

When an e-learning environment is applied, student satisfaction should be considered in evaluating the effectiveness of e-learning. The degree of student learning satisfaction with an e-learning environment plays an important role in the adoption of e-learning or blended learning and in evaluating the effectiveness of distance learning.( So and Brush,2008; Zhu, (2012) ). Butorac et al. (2011) asserted that continuous and careful monitoring of learner's satisfaction is important for the success, feasibility and viability of elearning. student satisfaction in e-learning environments is a critical issue and has been questioned in some research (So \& Brush, 2008) .Regarding student satisfaction and collaborative learning, Kitchen and McDougall (1998) found that the majority of participants in their study rated their collaborative learning experiences as good or excellent. Similarly, Jung, Choi, Lim, and Leem (2002) reported that students who participated in online collaborative tasks expressed higher levels of satisfaction with their learning process compared to those who engaged in task-oriented interaction with their instructor. Clarity of design, interaction with instructors, and active discussion in the context of the course (Swan, 2001), will enhance students' satisfaction toward e-learning. 


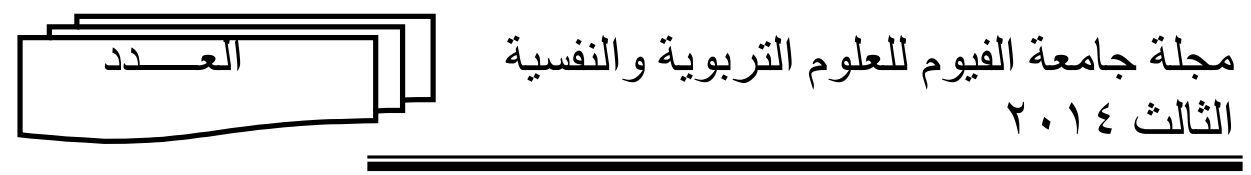

Zhu (2011) conducted a study that aimed at examining student satisfaction and performance in online collaborative learning involving students in two different cultural contexts. A parallel e-learning environment with online collaborative group work was implemented for a group of Chinese first-year students from a national comprehensive university in Beijing, China and a group of Flemish first-year students from a regional comprehensive university in Flanders, Belgium. Differences and similarities with regard to student (dis)satisfaction and their performance are analyzed and discussed from a cross-cultural perspective.

In the same context, Liaw (2008) investigated learners' satisfaction, behavioral intentions, and the effectiveness of the Blackboard e-learning system. A total of 424 university students were surveyed using a standard questionnaire. The results showed that perceived self-efficacy is a critical factor that influences learners' satisfaction with the Blackboard elearning system. Perceived usefulness and perceived satisfaction, both contribute to the learners' behavioral intention to use the e-learning system. Furthermore, e-learning effectiveness can be influenced by multimedia instruction, interactive learning activities, and e-learning system quality. This research proposed a conceptual model for understanding learners' satisfaction, behavioral intention, and effectiveness of using the e-learning system. 


\section{An analytical view of Students Interaction Ibtesam Al-Nahed Hania Al-Shanawani}

Zhu's (2012) study focused on examining the satisfaction, online performance, and knowledge construction through peer interaction of students in different cultural contexts. For this purpose, a parallel e-learning platform and course design was set up in both a Flemish university and a Chinese university. The e-learning platform is an open-source platform based on Dokeos. Efforts were made to make the learning design as similar as possible in the two educational settings. The same lectures were presented and the same online tasks were assigned to both the Chinese and Flemish groups during one academic semester. Students were able to use different sources such as articles, books, websites, photos, newspapers, and audio/video fragments to explain the different elements theoretically as well as to provide examples. They also needed to try to make the wiki attractive/inviting for readers. Students were divided into groups of six members. Students were trained on how to use the e-learning system, how to participate in group discussions, and how to create wiki documents and pages. Differences and similarities of the two groups of students with regard to satisfaction, learning process, and achievement were analyzed. The Chinese students reported a higher level of satisfaction with the e-learning functions, online collaboration, and peer contribution

On the other hand, students in e-learning courses are likely to be dissatisfied and frustrated with the following factors: a) unclear expectations from instructors, (b) tight 


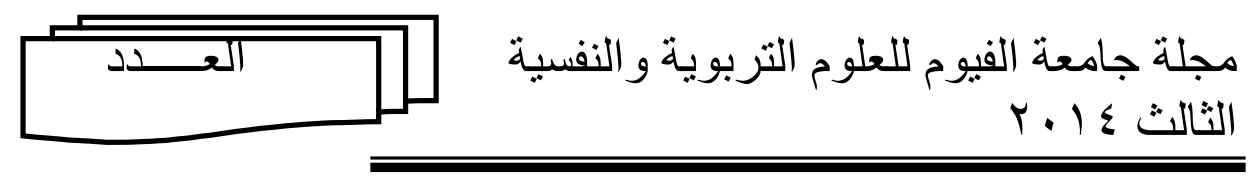

timeline, (c) workload, (d) poor software interface, (e) slow access, and (f) no synchronous communication (Liaw, 2008)

So \& Brush, (2008) conducted a study that aimed at examining the relationships of the students' perceived levels of collaborative learning, social presence and overall satisfaction in a blended learning environment. This research studied the relationship of these three variables and identified critical factors related to them. The participants were 48 graduate students who took a blended-format course in health education and worked on a collaborative group project related to the development of a comprehensive HIV-AIDS prevention plan.

Data was collected from the Student Perception Questionnaire and face-to- face interviews. The analysis of quantitative data indicated that student perceptions of collaborative learning have statistically positive relationships with perceptions of social presence and satisfaction. This means that students who perceived high levels of collaborative learning tended to be more satisfied with their distance course than those who perceived low levels of collaborative learning. Similarly, students with high perceptions of collaborative learning perceived high levels of social presence as well. Surprisingly, the relationship between social presence and overall satisfaction was positive but not statistically significant. Interview data revealed that (a) course structure, (b) emotional support, and (c) communication medium were 


\section{An analytical view of Students Interaction Ibtesam Al-Nahed Hania Al-Shanawani}

critical factors associated with student perceptions of collaborative learning, social presence, and satisfaction. Explanations about findings and implications for instructional design are discussed in the conclusion.

By considering the responses of students who participated in e-learning courses, it is possible to better understand the reasons why students are often dissatisfied with the e-learning experience. Bouhnik and Marcus (2006) stated that students' e-learning dissatisfaction was based the following disadvantages:

Lack of a firm framework to encourage students to learn.

A high level of self-discipline or self-direct is required.

Absence of a learning atmosphere in e-learning systems.

The distance-learning format minimizes the level of contact, as well as the level of discussion, among students.

In other words, e-learning lacks interpersonal and direct interaction among students and teachers.

The learning process is less efficient. When compared to the face-to-face learning format, e-learning requires students to dedicate more time to learn the subject matter.

Some researchers have attempted to identify particular student characteristics or other factors that can be used to predict whether a student might drop out of, or otherwise fail 


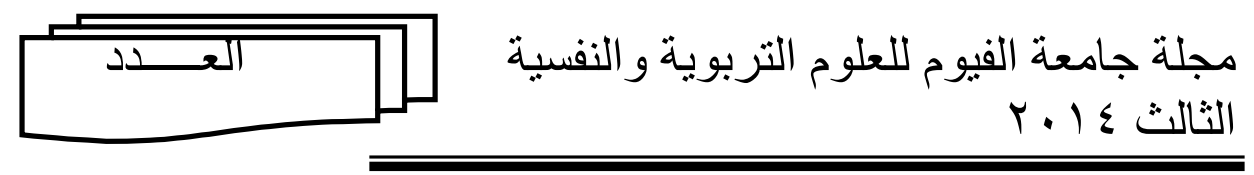

to achieve satisfactory results in an e-learning course (Bouhnik \& Marcus, 2006).

As the results of the learning activities in the e-learning system the students should feel the satisfaction in their learning. The designers - instructors can enhance satisfaction of students with following these strategies

(Yengin et al. 2010):

- Provide unexpected rewards (such as games)

- Implement positive outcomes (Give results - feedbacks immediate)

- Avoid negative punishments

- Scheduling - matching the course according to the students expectations

- Transfer knowledge into real world settings (Use simulations)

- Be fair in the test results

2.6. Content management for students with blended learning environment:

The use of e-learning environments to support teaching and learning has had great impact on the way content is developed and managed. In most cases, both teachers and students have had to re-adapt the way they prepare, access and engage with educational matter.(Mwanza \& Engeström , 2005). Producing effective and interactive digital contents is a critical issue that challenges instructors of blended courses (Alebaikan \& troudi,2010b). Blended learning is the combination of both 


\section{An analytical view of Students Interaction Ibtesam Al-Nahed Hania Al-Shanawani}

traditional instruction and e-learning. In this way not only students benefit from the interactivity in the classroom environment, but also they got familiar with the technology and easily manages their work. They are provided with the most features of e-learning like independence from time and place, communication with teacher and peers from anywhere and anytime by being in a virtual instructional environment. From the teachers' point of view, the integration of technology into the classroom environment should be successfully implemented.

Like in traditional learning, blended learning also requires organizing and structuring the content and makes content easily accessible. According to Robertson (2003), a CMS can be used to create, store, update, publish and present information. For educational purposes, a CMS can be used within a course in order to watch the workflow of tasks, to reach course content and to submit assignments. Furthermore, using CMS as a support to classroom instruction will form the structure for blended learning.

When used for educational purposes, effective management of online information (text, audio, video, animation, interactive applications, question bank etc.) and applications (store, add, modify, update etc.) is very important for both instructors and students (Altun et al. , 2008). A course management system (CMS) will typically promote communication and interaction by using a discussion board, 


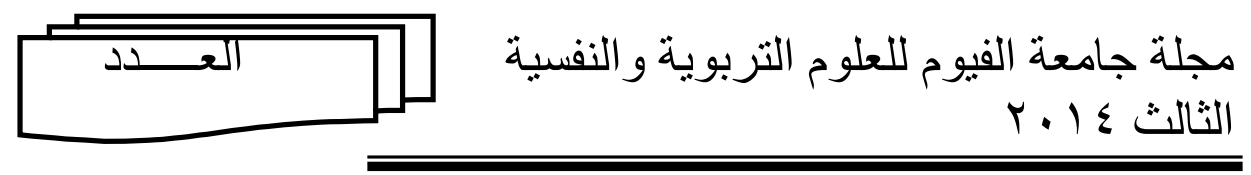

chat, and course e-mail both students and instructors will seek following features to carry on instructional activities.

- Effective management of information

- Easy navigation

- Easy to access and use

- Clear directions and tasks

- Hierarchically organized

- Interactivity

- Different interfaces and functions for different user groups

- Flexible user and group management

- Easy to use communication tools (Palloff \& Pratt, 2001; Sloman, 2001).

Traditionally, the task of managing educational content in learning institutions has been the responsibility of teachers and archivist or librarians. However, the current surge to implement information and communication technologies (ICT) within teaching and learning processes has created an inevitable need to store,access and distribute educational resources via technology-based systems, particularly databases and web-based systems.

Alebaikan (2011) pointed out that identifying the lecturers' technical and teaching abilities that enable them to succeed in this new environment helps in implementing blended courses .Also, Negative attitudes towards teaching blended courses could be a result of inadequate skills, not 


\section{An analytical view of Students Interaction Ibtesam Al-Nahed Hania Al-Shanawani}

believing in the effectiveness of blended learning, or avoiding the extra workload of transferring to blended courses.

In his study, Liaw (2008) talked about how instructors and learners manage content in the Blackboard System. The blackboard homepage provides overall course information (as shown in Fig. ...). It includes the syllabus, the textbook's information, assessment, and other information related the course. Teaching/learning materials (as shown in Fig. ....), in the form of PowerPoint slides, MS Word, Acrobat PDF documents, and video files can be presented through Blackboard to allow for anytime, anywhere access for students. The Discussion Board is a very useful tool for both instructors and students. The instructors can post instructions on how to prepare for an upcoming lecture, while the students can post any queries they have regarding the subject, from questions about assignments, to technical problems with the website. Responses from their peers, instructors, or technical staff can help to promptly clarify students' problems.

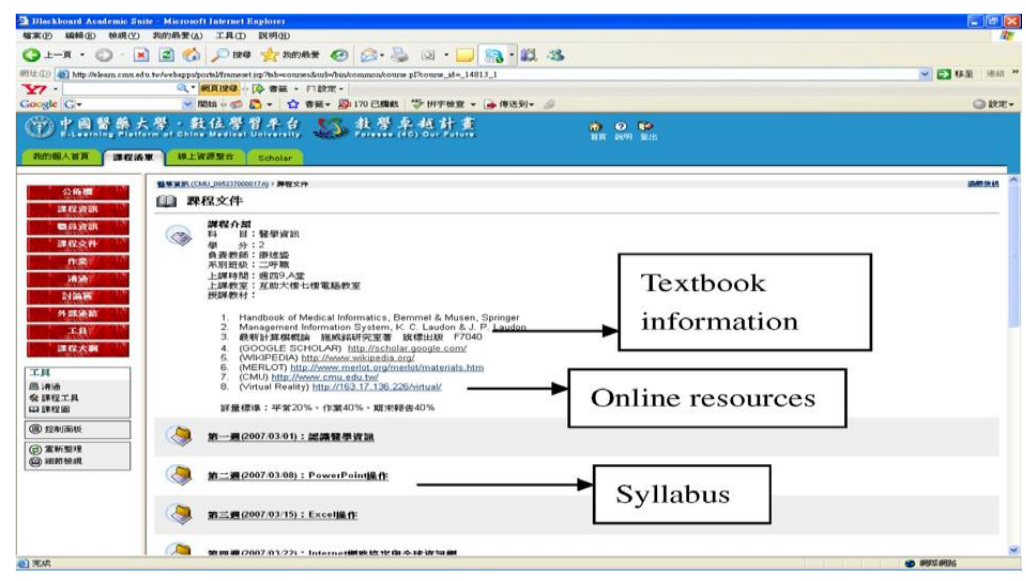




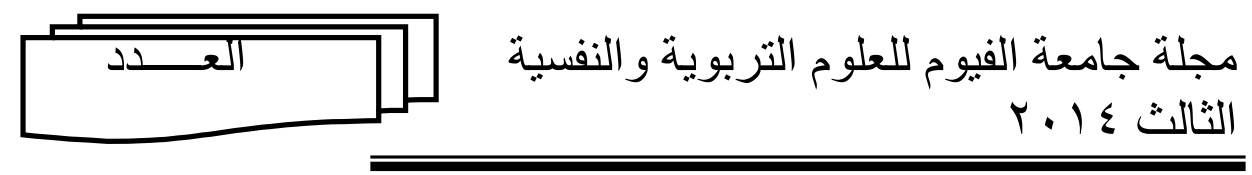

Figure (4): Overall course information

One of the solutions which can be helpful for both students and teachers in an e-learning environment is to use content management systems. A Content Management System (CMS) is defined as a combination of three distinct concepts by Lurie (2002): content, process and technology/software. Content is the text, graphics, animation, sound and video and all other media that comprise the base for the system. It is always crucial to be arranged in order to present more flexible, interoperable and manageable environments for users. $\boldsymbol{A}$ process is defined as the sets of activities which take one or more inputs and execute actions to produce outputs. These inputs can be performed by the system, the user, by someone else entirely, or by a combination of actors. For our purposes, a process refers to the ways integrated into the system in order for users to perform tasks like download, publish, and share. Lastly, you need technology/software to perform your process to control your content over the Internet. Furthermore, it is clear CMS has no meaning without users; people can be considered as another important concept for CMS.

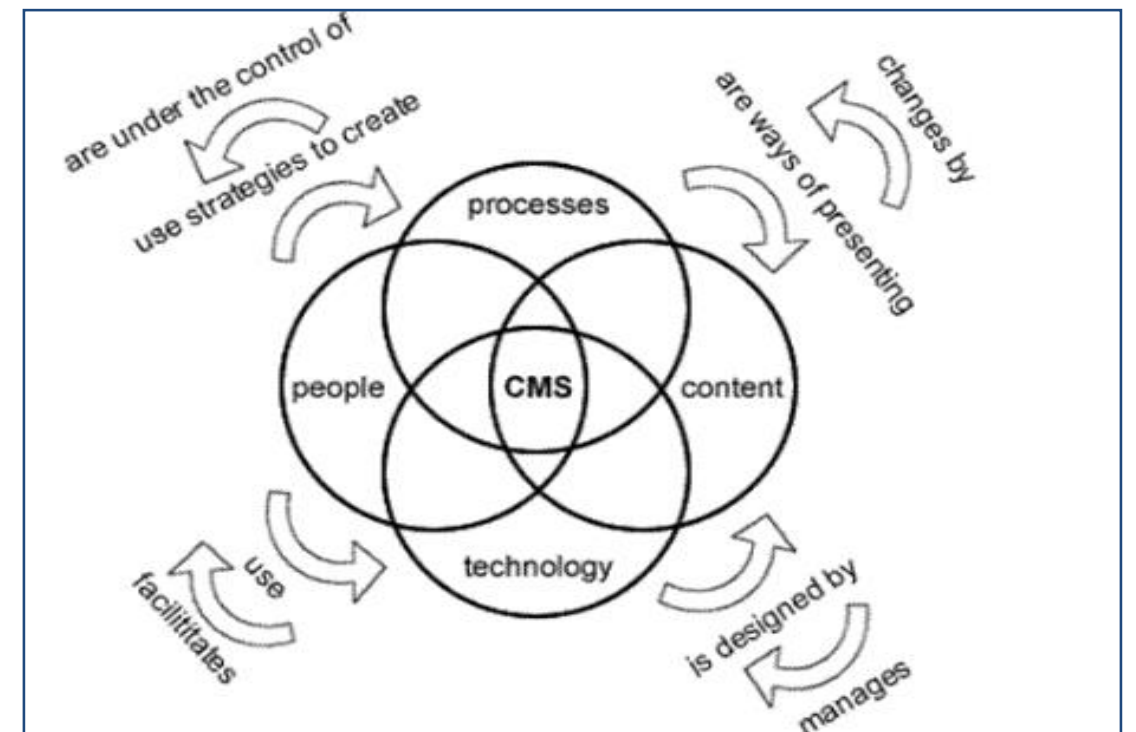




\section{Figure (5): The workflow in CMS (from Altun et al. (2008))}

According to Altun et al. (2008), basic purpose of any CMS is to manage information workflow in a database and publish the content onto web environment. For educational purposes, a CMS can be used within a course in order to watch the workflow of tasks, to reach course content and to submit assignments. Furthermore, using CMS as a support to classroom instruction will form the structure for blended learning.

Altun et al. (2008) investigated the perceptions of learners about using a CMS as a support tool for classroom instruction, i. e. for blended learning, this research utilized qualitative research methodology. The pre-service teachers of various grades from faculties of education of one private and one state university were the participants for this study. Participants used ENIYISI in different courses offered by different instructors. While using ENIYISI, learners are expected to create, store and modify files, organize these files for future use and share files with others. For achieving this goal, weekly assignments were given to participants and they are expected to share their own work with peers and 


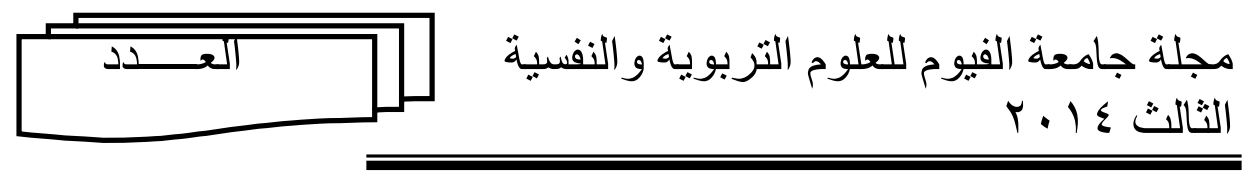

communicate through the system. During the implementation phase of ENIYISI, 191 students in six different courses from three different universities registered to the system. Among 191 students, 65 of them voluntarily filled out the questionnaire. This questionnaire included a section for demographic information and the following guiding questions:

- Evaluate the tools' contribution to the system usage. Please write down your thoughts in detail.

- Which features you favored the most? Please explain in detail.

- Explain in detail the obstacles you faced while using the system.

- What can be done to improve the usability of ENIYISI? Please write down your suggestions.

- Please state your positive/negative ideas about features (my place, communities, communication, search and admin panel) provided in ENIYISI.

The findings of this study indicated that participants initiated collaboration and sharing within a community without prior instruction.

Alebaikan \& Troudi (2010) recommended that the transition to a blended learning university environment is facilitated by providing the following: a thorough orientation for new students and instructors; student computers 


\section{An analytical view of Students Interaction Ibtesam Al-Nahed Hania Al-Shanawani}

laboratories; instructor training programs, and a series of easy to use curriculum design ideas for instructors. In addition, it is recommended to use feedback from students and instructors via regular course evaluations and other means to accurately inform university action plans. The concept of managing content incorporates the editorial processes of gathering, creating new, or selecting suitable educational materials from existing resources for web delivery (Mwanza \& Engeström , 2005)

Altun et al. (2008) investigated the perceptions of learners about using a CMS as a support tool for classroom instruction, i. e. for blended learning, this research utilized qualitative research methodology. A qualitative paradigm is appropriate when researchers do not have any control over the setting and explore the lived experiences of participants.

Yengin et al.(2010) provided us with a basic model to help educators decide their teaching model. Figure (...) shows the summary of basic components of this model.

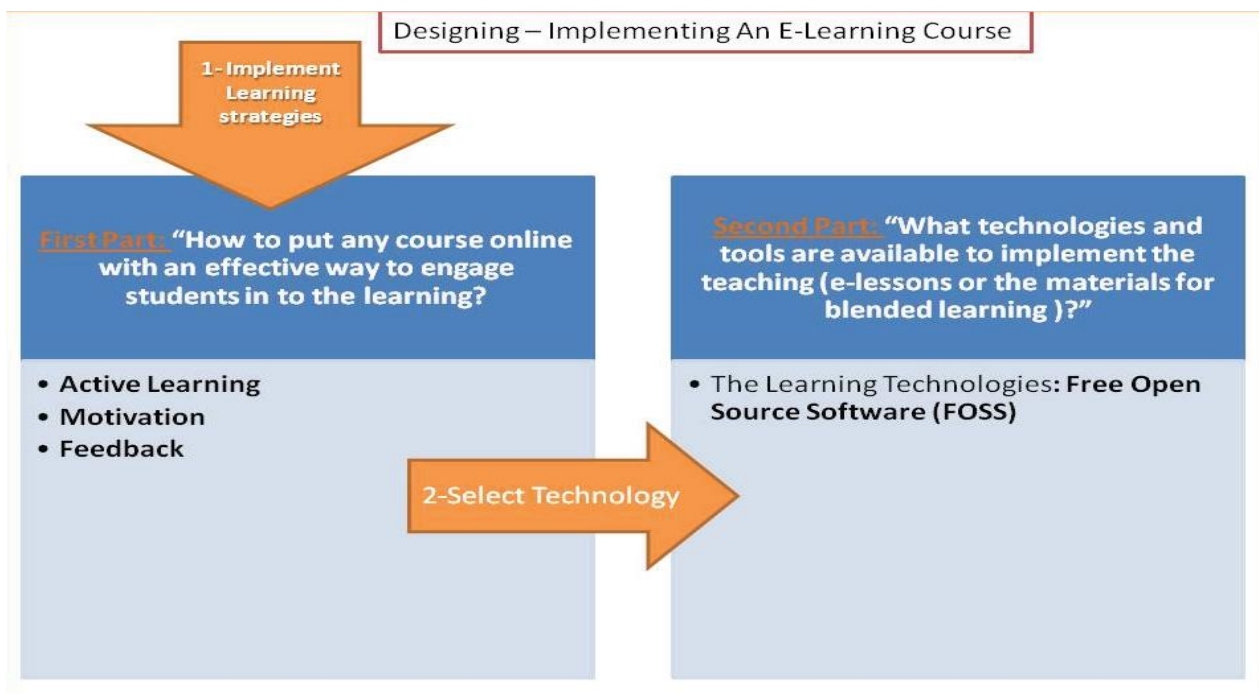




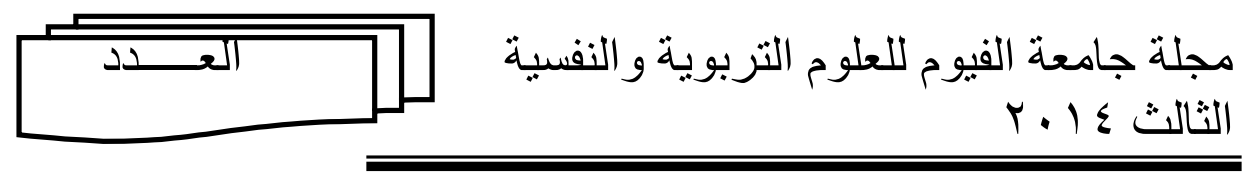

Figure ( 6 ). Model for Designing and Implementing an E-

\section{Learning Course}

In this model in first part there are issues about deciding learning strategies of e learning. This part covers three issues to implement an e-learning program: Active learning, motivation and feedback. After understanding the first part of model in this paper, teachers can have general ideas how to build their own teaching in e-learning environments and how to put their lesson effectively. These ideas are very general and can be used as a base template.

\section{Active Learning}

The issue of making students to have a role actively in their learning and participate.

Active learning strategies shortly suggest putting students into the center of their learning.

\section{Motivation}

After the active learning strategies employed there are another issue of making students to have positive attitudes to the lessons and the learning activities.

\section{Feedback}

Feedback is the most important factor of any kind of communication, especially in learning. While designing and implementing learning activities teachers need to be very aware of providing good feedback. In e-learning the feedback has more importance because the lack of face to face interaction. 


\section{An analytical view of Students Interaction Ibtesam Al-Nahed Hania Al-Shanawani}

Second Part: "What technologies and tools are available to implement the teaching?"

\section{Free Open Source Software}

As decision maker teachers also need to become familiar to the existing technologies. There are several commercial tools readily available. Also there are totally free tools to consider.

\subsubsection{Learning Management System (LMS):}

For the sake of improving the quality of learning and access to higher education in Saudi Arabia, the Ministry of Higher Education has established the National Plan for Information Technology which encourages e-learning and distance education in higher education. In 2006, the National Plan for Information Technology established the National Elearning and Distance Learning Centre. This Centre provides technical support, tools, and the means necessary for the development of digital educational content in higher education throughout the country, and is a vehicle by which all university sectors can become standardized. In addition, it has established a Learning Management System (LMS) called 'Jusur' promoting materials for university courses. learning management system (LMS) is a software application or Webbased technology used to plan, implement, and assess a specific learning process. An LMS is a system designed to automate the administration of training events. LMS functionality includes user registration, tracking courses in a catalog, and recording data from learners; it also has reporting features for analysis purposes. A learning management system 


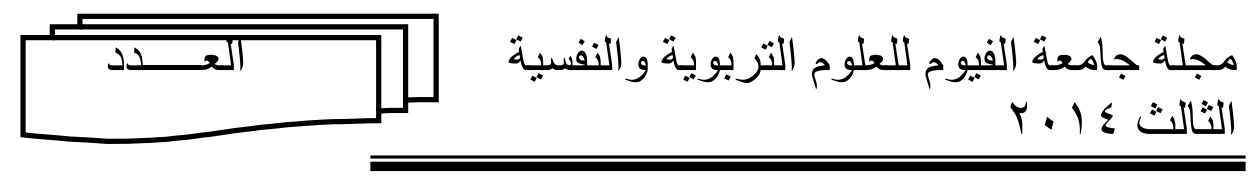

provides an instructor with a way to create and deliver content, monitor student participation, and assess student performance. A learning management system may also provide students with the ability to use interactive features such as threaded discussions, video conferencing, and discussion forums.

The focus of an LMS is to manage learners, keeping track of their progress and performance across all types of training activities. It performs heavy-duty administrative tasks, such as reporting to HR and other ERP systems but isn't generally used to create course content. A good LMS provides an infrastructure that enables a company to plan, deliver, and manage learning programs in any format it chooses

A learning management system plans, delivers and manages all the learning needs of an organization. An LMS is designed keeping an eye on the corporate learning market. It makes courses available, makes enrollments and develops its confirmation, checks learner eligibility, develops reminders of class schedules, records course completion, develops tests, communicates the completion of the course to the learner's employer and generates follow-up correspondence to the learner. It provides a platform to manage blended learning that includes conventional classroom learning and online learning. An LMS can also be used to record and assess training satisfaction. In addition, it can generate reports such as the number of students enrolling in particular courses, or aggregated records of student performance in particular courses. 


\section{An analytical view of Students Interaction Ibtesam Al-Nahed Hania Al-Shanawani}

\section{The basic functions of an LMS include:}

- Registration of learners

- Tracking participation in courses

- Testing

- Conducting follow-up discussions

- Transferring information to other systems including the HR and ERP

- Fee processing and fee transfer among departments

- Scheduling courses

- Managing skills

- Managing blended learning

\section{Context of the problem:}

One major challenge to be considered in the implementation of blended learning in Saudi universities is the adaptation of this element in the traditional university culture (Alebaikan\& Troudi, 2010b). Some instructors are against new technological methods as a replacement for face-to-face instructions that revealed a type of instructor resistance that should be taken into consideration. Conservative elements of the society see the Internet as a danger to societal norms because of its unethical content, while faculty in science disciplines see it as a powerful tool for work enhancement. faculty perceptions of the potential use of the Internet influence their attitudes towards blended learning.

\section{Aim of the Study:}




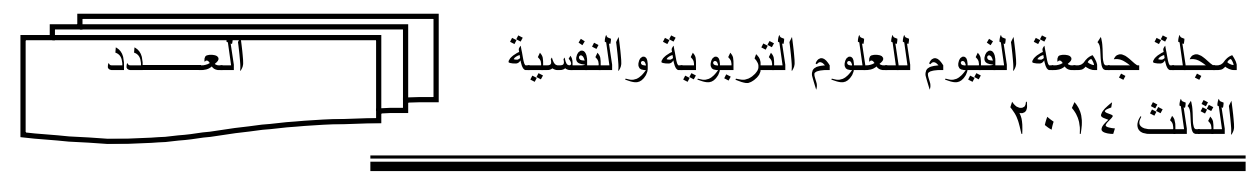

Results of the study will be significant for other populations who use e-learning environment through improving the quality of learning and access to higher education in Saudi Arabia. The primary aim of the present study is to specify King Saud University students' interaction with e-learning environment through:

1. measuring the level of their satisfaction with the e-learning environment.

2. Measuring students' attitudes towards e-learning environment (Blackboard)

3. Measuring the effect of students' attitudes on their learning styles negatively or positively.

4. Measuring students' level of collaborative learning.

5. Specifying the relationship between students' interaction and their academic level, number of courses taught using elearning, level of experience in computer and specialization.

6. Finding the relationship between students' attitudes toward e-learning, satisfaction, collaborative learning and the effect of their use of e-learning on their learning styles.

\section{Significance of the study:}

The present study is significant for both learners, instructors and course designers. In-depth understanding of the challenges of implementing blended learning and students interaction represented in their attitudes and satisfaction helps in uncovering the problems that face applying technology in the 


\section{An analytical view of Students Interaction Ibtesam Al-Nahed Hania Al-Shanawani}

educational system at Saudi Universities. The present study provides insights for curriculum designers, faculties and the decision-makers throughout higher education in Saudi Arabia. Thus, it will be of great value to other populations facing similar challenges of blended learning or e-learning environment.

\section{Statement of the Problem:}

There is a lack of research studies that have specifically examined students' interaction, represented in their satisfaction, attitudes and collaborative learning , with elearning environment. Thus, the present study is concerned with analyzing students interaction with e-learning environment at King Saud University.

\section{Delimitations of the study:}

\section{The present study is limited to :}

1. A group of college students at King Saud University, Faculty of Education, Departments of Special Education $(n=20)$ and Education and Early Childhood Education $(n=$ 20). The total number of students is 40 .

2. E-learning environment.

3. Interaction in e-learning environment.

8. Sample: 


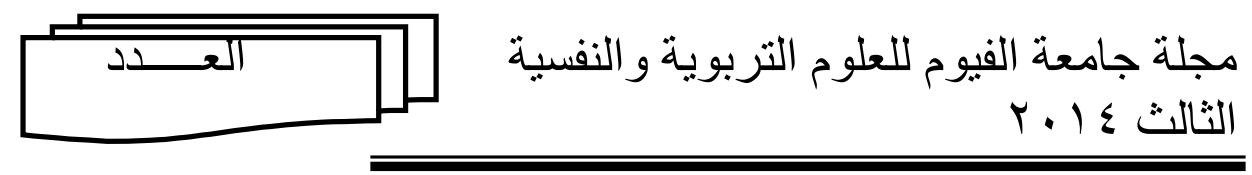

Forty of students (20 from department of Special Education and 20 from department of Education ), King Saud University. Their level of proficiency in using the internet is over average. All the participants are female. The number of previous online courses ranged from none to two.

\section{Research questions:}

1. What's the degree of college students interaction with e-learning environment?

- What's the level of college students attitudes towards e-learning environment?

- How does the e-learning environment affect college students' use of learning styles?

- What's the level of college students' satisfaction with e-learning environment activities?

- What's the level of college students collaborative learning in e-learning environment.

2. What is the effect of students' academic level, specialization, experience in computer and number of courses on their perceived levels interaction?

- What is the level of students' interaction attributed to the academic level?

- What is the level of students' interaction attributed to the specialization?

- What is the level of students' interaction attributed to the level of experience? 
An analytical view of Students Interaction Ibtesam Al-Nahed Hania Al-Shanawani

- What is the level of students' interaction attributed to the number of courses? 


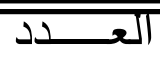

مجلة جامعة الفيوم للعلوم التربوية و النفسية

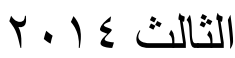

3. What are the relationships among students perceived levels of collaborative learning, effect of ss' use of elearning on their learning styles, attitudes and satisfaction?

\section{Definition of Terms:}

a. Blended Learning: So and Brush (2008) defined blended learning as any combination of learning delivery methods, including most often face-to-face instruction with asynchronous and/or synchronous computer technologies.

b. interaction: Interaction can be defined as a reciprocal communication process between human and human or between human and non-human (e.g., human-computer interaction) ( So and Brush,2008).

c.. Satisfaction: An affective learning outcome indicating the degree of: (a) learner reaction to values and quality of learning, and (b) motivation for learning ( So and Brush,2008).

The researcher will adopt So \& Brush (2008)'s definition.

d. E-Learning: A learning situation where instructors and learners are separated by distance, time, or both. E-learning uses network technologies to create, foster, deliver, and facilitate learning, anytime and anywhere (Raab, Ellis, $\boldsymbol{\&}$ Abdon, 2002)...The researcher will adopt this definition.

e. Collaborative learning: An instructional approach in which a small number of learners interact together and share their 


\section{An analytical view of Students Interaction Ibtesam Al-Nahed Hania Al-Shanawani}

knowledge and skills in order to reach a specific learning goal ( So and Brush,2008).

The researcher will adopt So \& Brush (2008)'s definition.

f. Content Management System (CMS) is defined as a combination of three distinct concepts: content, process and technology/software ( Lurie ,2002).

g. Learning Management System (LMS): learning management system (LMS) is a software application or Web-based technology used to plan, implement, and assess a specific learning process

\section{Method:}

A case study methodology was used to investigate students interaction with e-learning environment (Blackboard). The researchers used multiple tools for collecting data in depth. The case selection is based on participants' use of elearning method and work collaboratively in groups for one semester At the time of the present study participants were studying Computer through two different departments; Special Education and Early Childhood Education .Content was delivered through learning management system which was employed to facilitate online learning activities. Each interview took approximately 7-10 minutes

\subsection{Subjects (participants)}

In this research, the Blackboard e-learning system was conducted in King Saud University, College of Education. The 


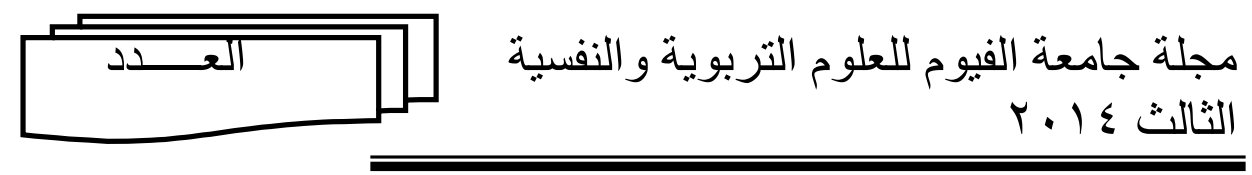

present study comprised a group of third and fourth levels college students who use the Blackboard system as their primary assisted leaning tools at King Saud University, College of Education, Departments of Special Education and Education and Early Childhood Education, $n=19$.

\subsection{Tools:}

Qualitative methods were used to obtain rich descriptive data about students' interaction with e-learning environment. This study conducted a survey to understand learner attitudes toward e-learning environment. Two different tools were designed ; face-to-face interview and The Collaborative Learning and Satisfaction Questionnaire(CLS). Both the Faceto-face interview and The collaborative learning and satisfaction questionnaire(CLS) are adopted from So and Brush(2008) and are validated after simple modification 11.2.1. Face-to-Face Interview(see appendix A).

Students were asked to participate in face-to-face interviews. Each interview took approximately 7-10 min. The interview questions were open-ended to allow the researcher to explore issues raised by the participants. Some of the questions included: What were the major differences of collaboration with classmates between traditional and distance courses? How important was collaboration with classmates to your satisfaction with this course? What would have improved your collaboration with classmates? After interviewing students data were transcribed, analyzed, verified, and reported. 


\section{An analytical view of Students Interaction Ibtesam Al-Nahed Hania Al-Shanawani}

\subsubsection{The Collaborative Learning and Satisfaction (CLS)}

Questionnaire: (see appendix B).

The questionnaire originally consisted of five sections and 38 items . It was developed to measure students levels of collaborative learning, satisfaction, attitudes towards elearning and the effect of students use of e-learning on their learning styles.

Section 1 (general information): four demographic items

Section 2 (Attitudes scale): it consists14 items divided into two parts:

-Students' attitudes towards e-learning environment (6 items).

-Effect of students' use of e- learning on their learning style(8 items).

- Section 3(satisfaction scale): it consisted of sentences that measure students' satisfaction with e-learning environment.

Section 4 (Collaborative learning scale): 13 items were constructed to measure students' perspectives on preferences to group versus individual work and preferences to online interaction versus face to face interaction, amount of collaboration and overall satisfaction with collaborative learning. After using the Blackboard e-learning system for ...... months, participants were asked to complete the CLS questionnaire The questionnaire, including a cover letter, was distributed to participants during class. All subjects were asked 


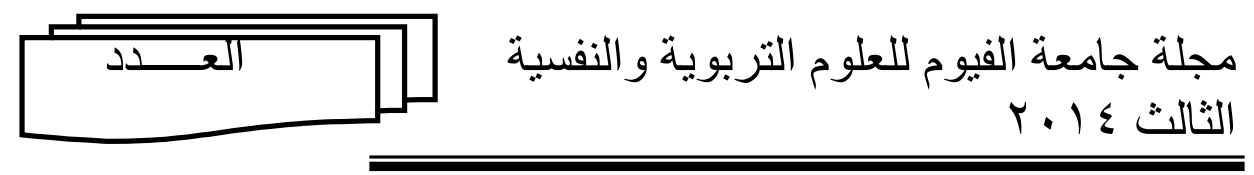

to respond to the questionnaire and their responses were guaranteed confidentiality. The mean scores of each participant were rank-ordered and divided into high, medium, and low level groups. Students with different levels of collaboration and satisfaction were identified from the student profile. Random numbers were then assigned to each student $(n=19)$. Attitudes toward e-learning: Participants were asked to indicate their attitudes toward e-learning. These 8 questions were answered using a 5-point Likert scales (ranging from 1 which means "strongly disagree" to 5 which means "strongly agree'").

\section{Results :}

First Question:

To find an answer to the first question of the study which is: "What's the degree of college students interaction with e-learning environment?", and its subquestions:

- What's the level of college students attitudes towards e-learning environment?

- How does the e-learning environment affect college students' use of learning styles?

- What's the level of college students' satisfaction with e-learning environment activities?

- What's the level of college students collaborative learning in e-learning environment. 
An analytical view of Students Interaction Ibtesam Al-Nahed Hania Al-Shanawani

5-point Likert scale was used to measure means and standard deviations for students' responses as follows:

- First: the level of college students attitudes towards elearning environment? 


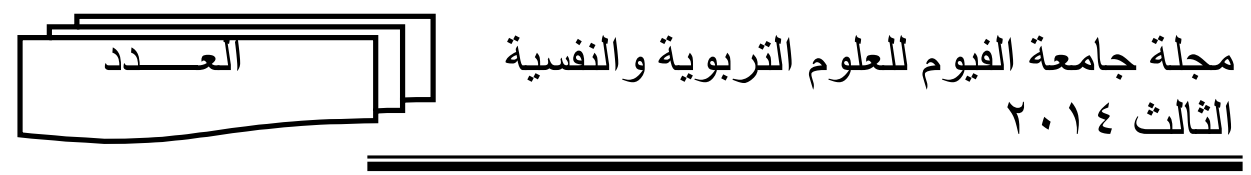

Table (1)

Means and standard deviations for students' attitudes towards e-learning environment

\begin{tabular}{|c|c|c|c|}
\hline Item & Number & M & SD. \\
\hline 1 & 19 & 4.10 & .80 \\
\hline 2 & 19 & 3.47 & .61 \\
\hline 3 & 19 & 3.47 & 1.02 \\
\hline 4 & 19 & 3.84 & .76 \\
\hline 5 & 19 & 4.05 & .77 \\
\hline 6 & 19 & 3.78 & .97 \\
\hline 7 & 19 & 2.47 & .96 \\
\hline 8 & 19 & 3.73 & .80 \\
\hline Whole items & 19 & 3.61 & 0.84 \\
\hline
\end{tabular}

According to 5-point Likert scale, Table (1) indicates that the mean for the whole items is average. Also, it indicates the students' responses to the seventh question were varied. And, the highest point was to all other seven items. Second: How does the e-learning environment affect college students' use of learning styles? 


\section{Table (2)}

Means and standard deviations for students' responses to use of e-learning and its effect on their learning styles

\begin{tabular}{|c|c|c|c|}
\hline Item & Number & M & SD. \\
\hline 1 & 19 & 4.26 & .73 \\
\hline 2 & 19 & 4.21 & .78 \\
\hline 3 & 19 & 3.26 & 1.14 \\
\hline 4 & 19 & 3.47 & .96 \\
\hline 5 & 19 & 2.89 & 1.24 \\
\hline 6 & 19 & 3.36 & 1.25 \\
\hline 7 & 19 & 2.63 & .95 \\
\hline 8 & 19 & 2.73 & .93 \\
\hline Whole items & 19 & 3.35 & 1.0 \\
\hline
\end{tabular}

Table(2) indicates that the mean and the standard deviation for the whole items are medium. Students responses to items of their' attitudes towards e-learning environment were varied. It was low for the seventh item and high for other items except the second which was to some extent high.

Thirdly: the level of college students' satisfaction with elearning environment activities: 


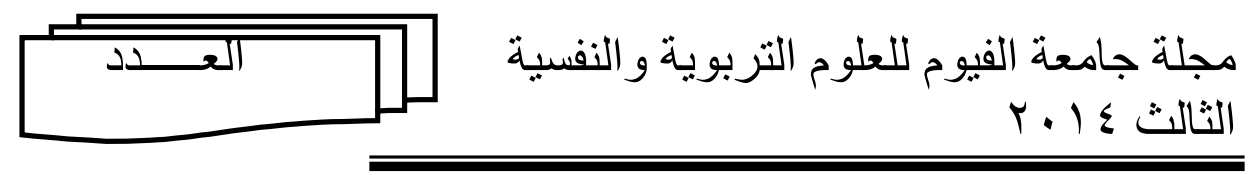

Table (3)

Means and standard deviations for students' responses to satisfaction scale.

According to 5-point Likert scale, the general mean

\begin{tabular}{|c|c|c|c|}
\hline Item & Number & M & SD. \\
\hline $\mathbf{1}$ & 19 & 3.36 & 1.01 \\
\hline $\mathbf{2}$ & 19 & 3.00 & 1.15 \\
\hline $\mathbf{3}$ & 19 & 3.05 & 1.17 \\
\hline $\mathbf{4}$ & 19 & 3.47 & .90 \\
\hline $\mathbf{5}$ & 19 & 4.10 & .45 \\
\hline $\mathbf{7}$ & 19 & 2.94 & 1.07 \\
\hline $\mathbf{8}$ & 19 & 2.63 & 1.01 \\
\hline $\mathbf{9}$ & 19 & 3.36 & .89 \\
\hline $\mathbf{1 0}$ & 19 & 3.57 & .60 \\
\hline $\mathbf{1 1}$ & 19 & 3.47 & .84 \\
\hline Whole items & 19 & 3.52 & .61 \\
\hline $\mathbf{1 9}$ & $\mathbf{3 . 2 6}$ & $\mathbf{0 . 8 8}$ \\
\hline
\end{tabular}

was middle. The table also shows that students responses to the items of their satisfaction with e-learning were varied . Means of items 6 and 7 were low. Other items were high.

Fourth: the level of college students collaborative learning in e-learning environment. 


\section{Table (4)}

Means and standard deviations for students responses to

\begin{tabular}{|c|c|c|c|}
\hline variables & Number & M & SD. \\
\hline 1 & 19 & 2.53 & 1.22 \\
\hline 2 & 19 & 3.37 & 0.96 \\
\hline 3 & 19 & 2.89 & 0.99 \\
\hline 4 & 19 & 2.74 & 0.99 \\
\hline
\end{tabular}

collaborative learning scale in e-learning environment. 


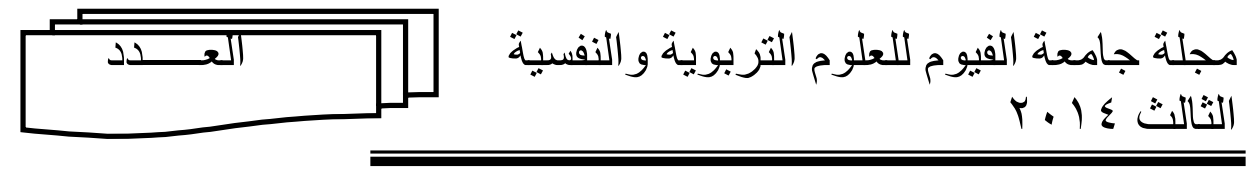

\begin{tabular}{|c|l|l|l|}
\hline 5 & 19 & 3.26 & 0.93 \\
\hline 6 & 19 & 2.95 & 0.85 \\
\hline 7 & 19 & 2.68 & 0.82 \\
\hline 8 & 19 & 3.32 & 1.00 \\
\hline 9 & 19 & 3.79 & 0.71 \\
\hline 10 & 19 & 3.47 & 0.96 \\
\hline 11 & 19 & 3.11 & 1.05 \\
\hline 12 & 19 & 3.89 & 0.66 \\
\hline 13 & 19 & 3.74 & 0.81 \\
\hline Whole items & $\mathbf{1 9}$ & 3.21 & 0.92 \\
\hline
\end{tabular}

Table (4) indicates that general mean of the whole items is medium according to 5-point scale. Other responses are ranged from low to high for all items

Second question :What is the effect of students' academic level, specialization, experience in computer and number of courses on their perceived levels interaction?

- What is the level of students' interaction attributed to the academic level?

- What is the level of students' interaction attributed to the specialization?

- What is the level of students' interaction attributed to the level of computer experience ?

- What is the level of students' interaction attributed to the number of courses? 


\section{An analytical view of Students Interaction Ibtesam Al-Nahed Hania Al-Shanawani}

To find an answer to the second question and its sub question, $\mathrm{T}$ - Test analysis was used as shown in the following tables:

\section{Table (5)}

T-Value for the study variables on basis of academic level

\begin{tabular}{|c|c|c|c|c|c|c|c|c|}
\hline variables & Level & N. & M. & SD & $\begin{array}{c}\text { T- } \\
\text { value }\end{array}$ & df. & Sig. & MD \\
\hline \multirow{2}{*}{$\begin{array}{c}\text { Students' attitudes toward e- } \\
\text { learning }\end{array}$} & 3 & 3 & 3.83 & 0.38 & \multirow{2}{*}{.905} & \multirow{2}{*}{17} & \multirow{2}{*}{.378} & \multirow{2}{*}{2.04} \\
\hline & 4 & 16 & 3.58 & 0.46 & & & & \\
\hline \multirow{2}{*}{$\begin{array}{l}\text { Effect of students' use of e- } \\
\text { learning on their learning } \\
\text { styles. }\end{array}$} & 3 & 3 & 3.25 & 0.57 & \multirow{2}{*}{$-.300-$} & \multirow{2}{*}{17} & \multirow{2}{*}{.768} & \multirow{2}{*}{-1.0} \\
\hline & 4 & 16 & 3.38 & 0.67 & & & & \\
\hline \multirow{2}{*}{ Satisfaction scale } & 3 & 3 & 3.55 & 0.36 & \multirow{2}{*}{.784} & \multirow{2}{*}{17} & \multirow{2}{*}{.444} & \multirow{2}{*}{2.94} \\
\hline & 4 & 16 & 3.28 & 0.56 & & & & \\
\hline \multirow{2}{*}{ Collaborative learning scale } & 3 & 3 & 3.13 & 0.56 & \multirow{2}{*}{$-.253-$} & \multirow{2}{*}{17} & \multirow{2}{*}{.804} & \multirow{2}{*}{-1.27} \\
\hline & 4 & 16 & 3.23 & 0.62 & & & & \\
\hline \multirow{2}{*}{ Whole scale } & 3 & 3 & 3.41 & 0.46 & \multirow{2}{*}{.230} & \multirow{2}{*}{17} & \multirow{2}{*}{.821} & \multirow{2}{*}{2.71} \\
\hline & 4 & 16 & 3.34 & 0.47 & & & & \\
\hline
\end{tabular}

Table (5) indicates that there are differences in the mean of scale's items and the mean of the whole scale between third level and fourth level as to ss' interaction with e-learning on basis of academic level. T-test also indicates that there are no statistical significant differences for the scale's four items and the whole scale between $3^{\text {rd }}$ and $4^{\text {th }}$ levels for ss' interaction with e-learning. This means there are differences but not statistically significant. This result may be attributed to the fact that ss did not fully interacted with e-learning environment. 


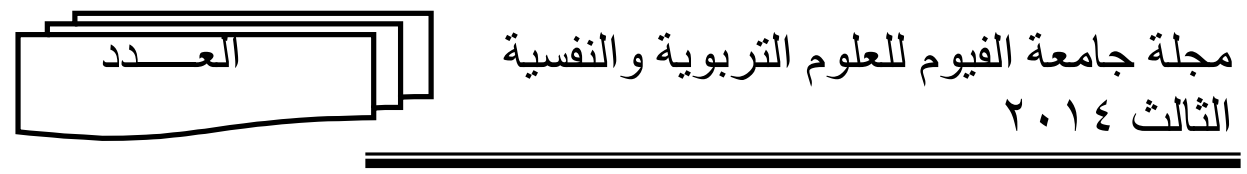

Table (6)

T-value for students' the study variables on basis of specialization

\begin{tabular}{|c|c|c|c|c|c|c|c|}
\hline variables & specialization & N. & M. & SD & $\begin{array}{c}\mathrm{T}- \\
\text { value }\end{array}$ & df. & Sig. \\
\hline \multirow{2}{*}{$\begin{array}{l}\text { Students' attitudes } \\
\text { toward e-learning }\end{array}$} & Education & 6 & 3.83 & 0.34 & \multirow{2}{*}{1.473} & \multirow{2}{*}{17} & \multirow{2}{*}{.159} \\
\hline & $\begin{array}{c}\text { Special } \\
\text { education }\end{array}$ & 13 & 3.52 & 0.47 & & & \\
\hline \multirow{2}{*}{$\begin{array}{l}\text { Effect of students' use } \\
\text { of e-learning on their } \\
\text { learning styles. }\end{array}$} & Education & 6 & 3.40 & 0.36 & \multirow[b]{2}{*}{.181} & \multirow[b]{2}{*}{17} & \multirow[b]{2}{*}{.859} \\
\hline & $\begin{array}{c}\text { Special } \\
\text { education }\end{array}$ & 13 & 3.34 & 0.76 & & & \\
\hline \multirow{2}{*}{ Satisfaction scale } & Education & 6 & 3.48 & 0.67 & \multirow{2}{*}{.904} & \multirow{2}{*}{17} & \multirow{2}{*}{.379} \\
\hline & $\begin{array}{c}\text { Special } \\
\text { education }\end{array}$ & 13 & 3.24 & 0.47 & & & \\
\hline \multirow{2}{*}{$\begin{array}{c}\text { Collaborative learning } \\
\text { scale }\end{array}$} & Education & 6 & 3.40 & 0.60 & \multirow[b]{2}{*}{.920} & \multirow[b]{2}{*}{17} & \multirow[b]{2}{*}{.370} \\
\hline & $\begin{array}{c}\text { Special } \\
\text { education }\end{array}$ & 13 & 3.12 & 0.60 & & & \\
\hline \multirow{2}{*}{ Whole scale } & Education & 6 & 3.51 & 0.38 & \multirow{2}{*}{1.022} & \multirow{2}{*}{17} & \multirow{2}{*}{.321} \\
\hline & $\begin{array}{c}\text { Special } \\
\text { education }\end{array}$ & 13 & 3.28 & 0.48 & & & \\
\hline
\end{tabular}

Table (6) indicates that there are differences in the means of scale's items between ss' responses on basis of specialization .

T-test shows that differences are not statistically significant.

\section{Table (7)}

\section{Means and standard deviations for students' interaction on basis of level of experience.}

\begin{tabular}{|c|c|c|c|c|}
\hline variables & experience & N. & M. & SD \\
\hline Students' attitudes toward & beginner & 3 & 3.833 & 0.473 \\
\hline
\end{tabular}




\section{An analytical view of Students Interaction Ibtesam Al-Nahed Hania Al-Shanawani}

\begin{tabular}{|c|c|c|c|c|}
\hline \multirow{2}{*}{ e-learning } & middle & 13 & 3.548 & 0.488 \\
\cline { 2 - 5 } & expert & 3 & 3.708 & 0.144 \\
\hline \multirow{2}{*}{$\begin{array}{c}\text { Effect of students' use of } \\
\text { e-learning on their } \\
\text { learning styles. }\end{array}$} & beginner & 3 & 2.875 & 0.250 \\
\cline { 2 - 5 } & middle & 13 & 3.346 & 0.627 \\
\hline \multirow{2}{*}{$\begin{array}{c}\text { Satisfaction scale } \\
\text { expert }\end{array}$} & 3 & 3.875 & 0.760 \\
\cline { 2 - 5 } & beginner & 3 & 3.424 & 1.022 \\
\cline { 2 - 5 } & middle & 13 & 3.280 & 0.477 \\
\hline \multirow{2}{*}{$\begin{array}{c}\text { Collaborative learning } \\
\text { scale }\end{array}$} & expert & 3 & 3.394 & 0.367 \\
\cline { 2 - 5 } & beginner & 3 & 3.333 & 0.911 \\
\cline { 2 - 5 } & middle & 13 & 3.077 & 0.564 \\
\hline \multirow{2}{*}{ Whole scale } & expert & 3 & 3.667 & 0.194 \\
\cline { 2 - 5 } & beginner & 3 & 3.367 & 0.657 \\
\cline { 2 - 5 } & middle & 13 & 3.281 & 0.458 \\
\hline & expert & 3 & 3.642 & 0.138 \\
\hline
\end{tabular}

Table (7) shows that there are differences in means between students based on experience in computer. ANOVA Analysis was used to test the differences among the three groups as follows.

\section{Table (8)}

One-way ANOVA analysis for difference of the variable of experience

\begin{tabular}{|c|c|c|c|c|c|}
\hline variables & $\begin{array}{c}\text { Sum of } \\
\text { squares(SS) }\end{array}$ & Df. & $\begin{array}{c}\text { Mean } \\
\text { squares } \\
\text { (MS) }\end{array}$ & f & sig \\
\hline $\begin{array}{c}\text { Students' } \\
\text { attitudes toward } \\
\text { e-learning }\end{array}$ & 14.537 & 2 & 7.269 & .542 & .592 \\
\hline Effect of & 96.219 & 2 & 48.109 & 2.003 & .167 \\
\hline
\end{tabular}




\begin{tabular}{|c|c|c|c|c|c|}
\hline الع ســدد & \multicolumn{5}{|c|}{ لثالث ع ا ـ بامعة الفيوم للعلوم التربوية و النفسية } \\
\hline $\begin{array}{c}\text { students' use of } \\
\text { e-learning on } \\
\text { their learning } \\
\text { styles. }\end{array}$ & & & & & \\
\hline $\begin{array}{c}\text { Satisfaction } \\
\text { scale }\end{array}$ & 8.480 & 2 & 4.240 & .110 & .896 \\
\hline $\begin{array}{l}\text { Collaborative } \\
\text { learning scale }\end{array}$ & 152.351 & 2 & 76.175 & 1.298 & .300 \\
\hline Whole scale & 509.306 & 2 & 254.653 & .746 & .490 \\
\hline
\end{tabular}

One-way ANOVA analysis shows that there are no statistically significant differences at the level of .05 between students' responses for the scale's items concerning students' interaction with e-learning environment.

- the level of students' interaction attributed to the number of courses?

\section{Table (9)}

\section{T-value for students' means on responses for scale' items based on number of computer courses}

\begin{tabular}{|c|c|c|c|c|c|c|c|}
\hline Item & $\begin{array}{l}\text { Number } \\
\text { of courses }\end{array}$ & $\mathrm{N}$. & M. & SD & $\begin{array}{c}\mathrm{T}- \\
\text { value }\end{array}$ & df. & Sig. \\
\hline \multirow{2}{*}{$\begin{array}{l}\text { Students' attitudes } \\
\text { toward e-learning }\end{array}$} & 1 & 6 & 3.58 & 0.37 & \multirow{2}{*}{$.227-$} & \multirow{2}{*}{17} & \multirow{2}{*}{.823} \\
\hline & 2 & 13 & 3.63 & 0.49 & & & \\
\hline \multirow{2}{*}{$\begin{array}{l}\text { Effect of students' } \\
\text { use of e-learning on } \\
\text { their learning styles. }\end{array}$} & 1 & 6 & 3.23 & 0.59 & \multirow{2}{*}{$\begin{array}{c}- \\
.567-\end{array}$} & \multirow{2}{*}{17} & \multirow{2}{*}{.578} \\
\hline & 2 & 13 & 3.41 & 0.68 & & & \\
\hline \multirow{2}{*}{ Satisfaction scale } & 1 & 6 & 3.17 & 0.51 & \multirow{2}{*}{.} & \multirow{2}{*}{17} & \multirow{2}{*}{.410} \\
\hline & 2 & 13 & 3.39 & 0.55 & & & \\
\hline Collaborative & 1 & 6 & 2.97 & 0.75 & - & 17 & .254 \\
\hline
\end{tabular}


An analytical view of Students Interaction Ibtesam Al-Nahed Hania Al-Shanawani

\begin{tabular}{|c|c|c|c|c|c|c|c|}
\hline learning scale & 2 & 13 & 3.32 & 0.51 & $\begin{array}{c}1.18 \\
0-\end{array}$ & \\
\hline \multirow{2}{*}{ Whole scale } & 1 & 6 & 3.20 & 0.54 & - & 17 & \multirow{2}{*}{.339} \\
\cline { 2 - 6 } & 2 & 13 & 3.42 & 0.42 & $.983-$ & 17 \\
\hline
\end{tabular}

Table (9) indicates that there are differences in the means of students' responses in both scale items means and the whole scale items based on number of electronic courses used. Ttest shows that there no statistically significant differences at the level of .05 for students' interaction in the scale's items based on the variable of number of courses.

\section{Third question:}

What are the relationships among students perceived levels of collaborative learning, effect of ss' use of e-learning on their learning styles, attitudes and satisfaction?

To answer this question, Pearson's product-moment correlation coefficient was calculated to find statistical relationships among students' perceived levels of satisfaction, collaborative learning, attitudes and students' use of elearning. Table (10) below shows the correlation coefficients of the four relationships. 


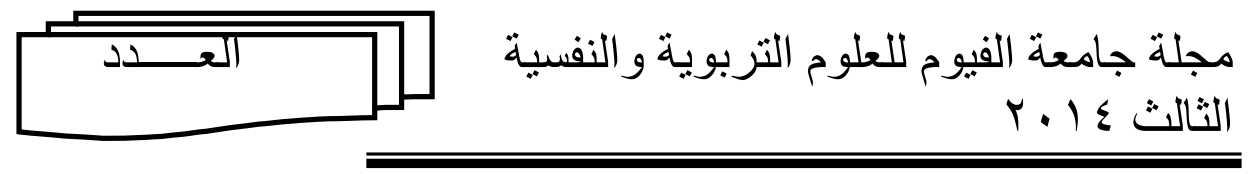

\section{Table (10)}

\section{Pearson Correlation between interaction variables}

\begin{tabular}{|c|c|c|c|c|c|}
\hline Variable & Attitudes & Effect & Satisfaction & $\begin{array}{l}\text { Collaborative } \\
\text { learning }\end{array}$ & $\begin{array}{l}\text { Whole } \\
\text { scale }\end{array}$ \\
\hline \multirow[t]{2}{*}{ Attitudes } & 1 & $.464^{*}$ & $.723^{* *}$ & $.546^{*}$ & $.795^{* *}$ \\
\hline & & .045 & .000 & .016 & .000 \\
\hline \multirow[t]{2}{*}{ Effect } & & 1 & .268 & $.524^{*}$ & $.685^{* *}$ \\
\hline & & & .268 & .021 & .001 \\
\hline \multirow[t]{2}{*}{ Satisfaction } & & & 1 & $.662^{* *}$ & $.824^{* *}$ \\
\hline & & & & .002 & .000 \\
\hline \multirow{2}{*}{$\begin{array}{l}\text { Collaborative } \\
\text { learning }\end{array}$} & & & & 1 & $.897^{* *}$ \\
\hline & & & & & .000 \\
\hline \multirow[t]{2}{*}{ Whole scale } & & & & & \\
\hline & & & & & \\
\hline
\end{tabular}

\section{*. Correlation is significant at the 0.05 level (2-tailed).}

\section{**. Correlation is significant at the 0.01 level (2-tailed).}

Table (10) indicates that there is a statistically significant correlation at the level of (.01) between students' attitudes toward e-learning environment, its use as a learning style, their satisfaction and collaborative learning and interaction as a whole with e-learning environment. The strongest correlation was between students' attitudes and their satisfaction with elearning (.723), then, between satisfaction and collaborative learning. The general correlation among the four variables are 
also strong. The following figure shows the correlation between the four variables:

Collaborative satisfaction effect of use attitudes Learning

Figure ( 7 ): Correlation between interaction variables 


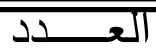

مجلة جامعة الفيوم للعلوم التربوية و النفسية

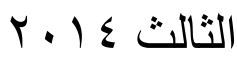

\section{Discussion and conclusion.}

\section{Discussion:}

Several researchers found that students had difficulty adjusting to blended learning (Aycock, Garnham, \& Kaleta, 2002; Bonk, Olson, Wisher, \& Orvis, 2002). Aycock et al. (2002), from the experiences of designing and teaching hybrid courses, suggested that students' poor time management skills rather than technologies was a significant obstacle. Another problem in blended learning is that when several components in a learning environment are not well integrated, this can increase the extraneous or ineffective cognitive load in learning processes. These findings imply that simply turning classroom courses into blended formats do not necessarily provide students with more interactive and flexible learning experiences. More careful analysis of learners, contexts, and technologies are needed.

E-learning courses are recently used in King Saud university. Students may not be accustomed to this revolutionary system of learning. The blackboard system requires experience in using computer. Also, one or two elearning courses are not sufficient to form positive attitudes among students towards this new system . Technical problems may affect learners satisfaction and interaction with the elearning environment because students may find it easier to interact face-to-face with instructors than to face these technical problems with the site or the computer sets . But on 


\section{An analytical view of Students Interaction Ibtesam Al-Nahed Hania Al-Shanawani}

the other hand, The face to face interview revealed some important views towards e-learning environment in case these problems are solved.

The face to face interview revealed that students experienced a number of benefits from e-learning environment. They revealed that distance courses differ from traditional classrooms in the way of communicating assignments, receiving marks and the way they browse content. Also, in the blackboard system, communication and collaboration are faster. Others preferred communication in the traditional classrooms because communication and collaboration in the blackboard system are limited to sending and receiving assignments and content of the course. They are also not continuous. Most students expressed their satisfaction with the blackboard system because of getting any announcements concerning tests or sending others to all students at the same time. The flexibility of the blackboard system fostered a sense of autonomy and responsibility. Students' responses to the interview varied from their responses to the questionnaire. This variance may be due to the fact that they gave the interview more importance than the questionnaire . Face to face interviews can be interpreted to students in many ways to uncover anything that's obscure or not clear. But in the case of the questionnaire they may face difficulty in understanding items of it and consequently they may misinterpret the items and the aim behind each one. 


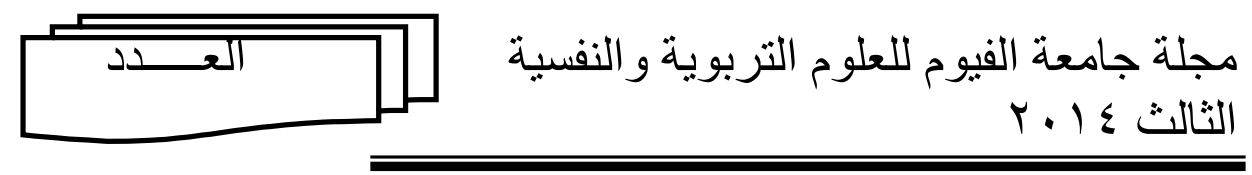

Students said that the blackboard system improved their collaboration to some extent due to the help they receive during collaboration in addition to the support they get from the instructor and the facility in getting information from peers. Most students are faced with technical problems that resulted in their frustration during work. Some of these problems are represented in poor internet connectivity, changing the browser, net load that affects the site negatively, the process of signing in and other maintenance problems. Sometimes the system does not work on some computer sets or other computer systems. Most students also suffer from the difficulty of overcoming these problems at home or outside work hours.

When asked to express their opinions toward preferring the blackboard system or the traditional face to face interaction, students answered that the blackboard system is better in sending assignments and single communication with instructors. Besides, the blackboard system saves time and effort and it's exciting and interesting one. Above all their absence does not represent difficulty in getting the content or the assignment. But, on the other hand the blackboard system does not give immediate feedback from instructors and does not provide them with face to face interaction which is very important for the process of communication.

The availability of students' names and the content facilitates communicate. Generally students pointed out that this system is important to cope with the global development. 


\section{An analytical view of Students Interaction Ibtesam Al-Nahed Hania Al-Shanawani}

In order to overcome the negative sides and the problems , students suggested some solutions such as decreasing the program steps, training on using the program, using the program in all courses, solving technical problems, changing the deadlines of sending assignments and training students in solving technical problems themselves. They also suggested keeping the system after study as a means of communication and as a content for study.

When asked about the role of e-learning environment on the students ' academic achievement, students answered,yes, it helps to cope with civilized development, getting to know new technological achievements that serve education and learning, in addition to using videos to facilitate communicating information. Most students (90\%) evaluated the blackboard system and the interaction with e-learning giving 3-7 points out of 10 .

Some studies such as Liaw (2008) revealed that although some students are highly experienced internet users, they do not have much e-learning experience. This view agrees with Alebaikan \& Troudi (2010) they assured that Saudi students have not experienced online learning, so a number of students may struggle with acquiring the crucial technical skills to function well in a blended learning environment . Liaw (2008) indicated that although learners believe that elearning is a useful assisted learning tool, they are concerned with the system quality, especially interactivity. They indicated that they needed more interactive and 


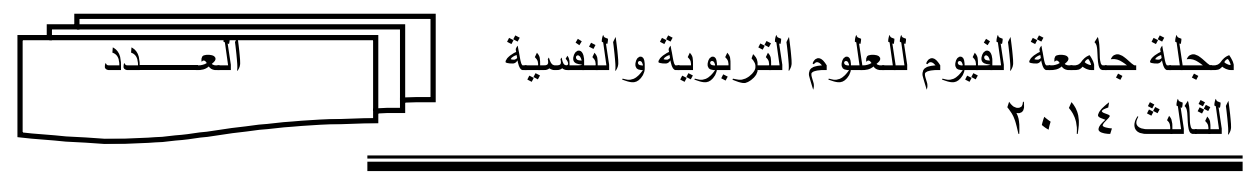

communicative functions and activities. Moreover, Alebaikan \& Troudi (2010:56) commented that "it may be challenging for Saudi universities to get students to adapt to the use of new learning strategies when they have been used to the traditional didactic, lecture-based classroom.". A study that was conducted by Al-Jarf (2005) on freshman students argued that some students did not take online instruction seriously as it was not used by other instructors and students at the college. Another challenge for instructors of blended courses may be producing effective and interactive digital contents (Alebaikan \& Troudi ,2010).

\section{Recommendations:}

It's recommended that students should have e-learning courses in LMS. These courses will help them understand the aims of e-learning and the benefits of using it in developing their skills in learning. 


\section{References}

Alebaikan (2011). A Blended Learning Framework for Saudi Higher Education. Available at: http://eli.elc.edu.sa /2011/sites/default/files/slidespdf

Alebaikan, R \& Troudi, S. (2010a). Online discussion in blended courses at Saudi Universities. Procedia Social and Behavioral Sciences,2, 507- 514.

Alebaikan, R \& Troudi, S. (2010b). Blended learning in Saudi universities: challenges and perspectives. ALT-J, Research in Learning Technology Vol. 18, No. 1, , 49-59

Al-Jarf, R.S. 2005. The effects of online grammar instruction on low proficiency EFL college students' achievement. Asian EFL Journal 7, no. 4: 166-90.

Allen, E., \& Seaman, J. (2003). Sizing the opportunity: The quality and extent of online education in the United States, 2002 and 2003.

Retrieved February 2004 from <http://www.sloanc.org/resources/sizing_opportunity.pdf > .

Aycock, A., Garnham, C., \& Kaleta, R. (2002). Lesson learned from the hybrid course project [electronic version]. Teaching with Technology Today, 8, Retrieved February 2, $2004 \quad$ from <http://www.uwsa.edu/ttt/articles/garnham2.htm>. 


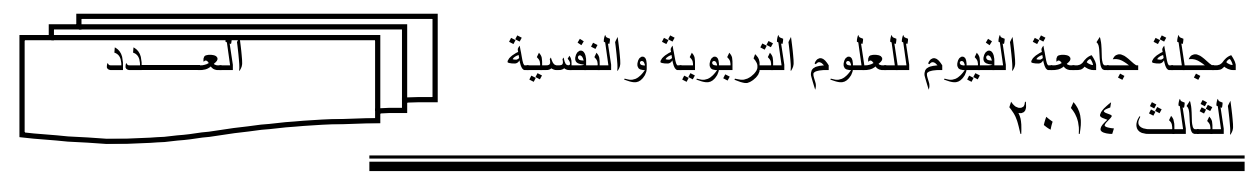

Bernard, R. M., Rubalcava, B. R., \& St-Pierre, D. (2000). Collaborative online distance learning: Issues for future practices and research.

Bersin \& Associates. (2003). Blended learning: What works?: An industry study of the strategy, implementation, and impact of blended learning: Bersin \& Associates.

Bouhnik, D., \& Marcus, T. (2006). Interaction in distancelearning courses. Journal of the American Society Information Science and Technology, 57(3), 299305.

Bonk, C. J., Olson, T. M., Wisher, R. A., \& Orvis, K. L. (2002). Learning from focus groups: An examination of blended learning. Journal of Distance Education, 17(3), 97-118.

Carr-Chellman, A., Dyer, D., \& Breman, J. (2000). Burrowing through the network wires: Does distance detract from collaborative authentic learning? Journal of Distance Education, 15(1), 39-62. Distance Education, 21(2), 260-277.

DeLacey, B.J., and D.A. Leonard. 2002. Case study on technology and distance in education at the Harvard Business School. Educational Technology and Society 5, no. 2:13-28.

Dönmez,O et al.(2010) How can we make use of learner interaction in online learning environments? / 


\section{An analytical view of Students Interaction Ibtesam Al-Nahed Hania Al-Shanawani}

Procedia Social and Behavioral Sciences 9, 783787

Driscoll, M. (2002, March 1, 2002). Blended Learning: Let's get beyond the hype. Elearning ,54.

Gabriel, M. A. (2004). Learning together: Exploring group interactions online. Journal of Distance Education, 19(1), 54-72.

Gaddis, B., Napierkowsk, H., Guzman, N., \& Muth, R. (2000). A comparison of collaborative learning and audience awareness in two computers-mediated writing environments. Paper presented at the Association for Educational Communications and Technology, Denver, CO.

Graham, C. (2006). Blended learning systems: definition, current trends, future directions. In C. J. Bonk, \& C. Graham (Eds.), The handbook of blended learning: Global perspectives, local designs (pp. 3-21). San Francisco, CA: Pfeiffer Publishing.

Graham, C. R., Allen, S., \& Ure, D. (2003). Blended learning environments: A review of the research literature. Unpublished manuscript, Provo, UT.

Graham, C R. (2004) . BLENDED LEARNING SYSTEMS: DEFINITION, CURRENT TRENDS, AND FUTURE DIRECTIONS . In Bonk, C. J. \& Graham, C. R. (Eds.). (in press). Handbook of blended learning: Global Perspectives, local designs. San Francisco, CA: Pfeiffer Publishing. 


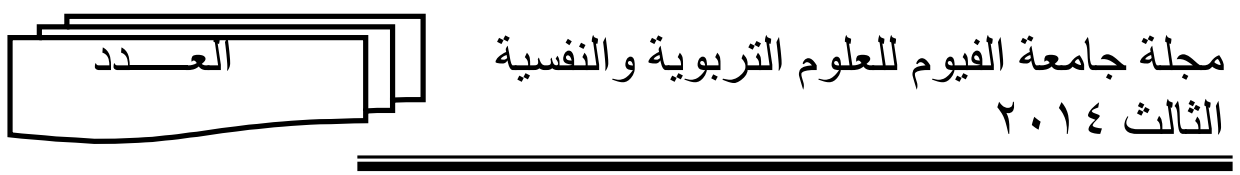

Garnham, C. \& Kaleta, R. (2002). Introduction to hybrid courses. Teaching with Technology Today, 8 (6). [Online].

Available:http://www.uwsa.edu/ttt/articles/garnham.htm.

Garrison, D. R., \& Kanuka, H. (2004). "Blended learning: Uncovering its transformative potential in higher education". The Internet and Higher Education 7 (2): 95-105

Graham, M., Scarborough, H., \& Goodwin, C. (1999). Implementing computer mediated communication in an undergraduate course - A practical experience. Journal of Asynchronous Learning Network, 3(1), $32-45$.

Hakkarainen, K., Lipponen, L., \& Jarvela, S. (2002). Epistemology of inquiry and computer-supported collaborative learning. In $\mathrm{T}$.

Hirumi, A. (2006). Analyzing and designing e-learning interactions. In Charles Juwah (Ed.), Interactions in online education implications for theory \& practice (pp. 46 - 71). New York: Routledge Publishing.

Huang,H. ; W., Wu, C.W., Chen, N. (2012). The effectiveness of using procedural scaffoldings in a paper-plussmartphone collaborative learning context. Computers \& Education, 59 , 250-259.

House, R. (2002). Clocking in column. The SpokesmanReview. 
Jung, I., Choi, S., Lim, C., \& Leem, J. (2002). Effects of different types of interaction on learning achievement, satisfaction and participation in Webbased instruction. Innovations in Education and Teaching International, 39(2), 153-162.

Kitchen, D., \& McDougall, D. (1998). Collaborative learning on the Internet. Journal of Educational Technology Systems, 27(3), 245.

Kim, J.Y.(2012) A study on learners' perceptional typology and relationships among the learner's types, characteristics, and academic achievement in a blended e-Education environment . Computers \& Education 59, 304-315.

Koschmann, R. Hall, \& N. Miyake (Eds.), CSCL 2: Carrying forward the conversation (pp. 129-156). Mahwah, New Jersey: Lawrence Erlbaum.

Hillman, D. C. A., Willis, D. J., \& Gunawardena, C. N. (1994). Learner-interface interaction in distance education: An extension of contemporary models. American Journal of Distance Education, 8(2), 30-42.

Jung I, Choi S., Lim C., \& Leem J. (2002). Effects of different types of interaction on learning achievement, satisfaction, and

participation in web-based instruction. Innovations in Education and Teaching International 39(2), pp. 153-162. 


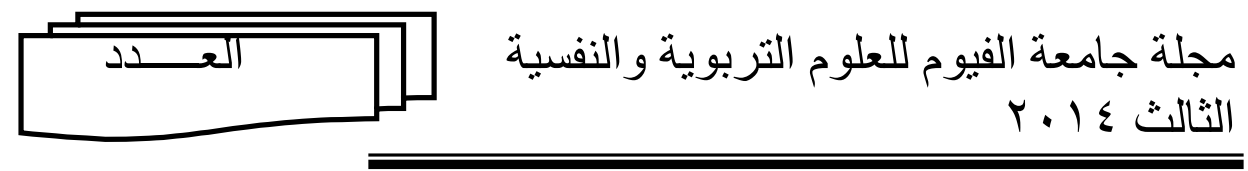

Liaw, S.-S.(2008) Investigating students' perceived satisfaction, behavioral intention, and effectiveness of e-learning: A case study of the Blackboard system. Computers \& Education 51, 864-873. 


\section{An analytical view of Students Interaction Ibtesam Al-Nahed Hania Al-Shanawani}

Liaw, S. S., \& Huang, H. M. (2007). Developing a Collaborative elearning System Based on Users' Perceptions. Lecture Notes in Computer Science, 4402, 751-759.

Lancaster J. W., McQueeney M. L., Amburgh J. A. V. (2011), Online lecture delivery paired with in class problembased learning ... . Does it enhance student learning? Currents in Pharmacy Teaching and Learning 3 23-29.

Liu, C. C., \& Kao, L. C. (2007). Do handheld devices facilitate face-to-face collaboration? Handheld devices with large shared display groupware to facilitate group interactions. Journal of Computer Assisted Learning, 23(4), 285-299. doi:10.1111/j.1365-2729.2007. 00234.x.

Lurie, I. (2002). A Web Content Management Blueprint: Planning for a content-rich, successful web site. Retrieved on September 14, 2007 from http://www.portentinteractive .com/library/cmsexplained.pdf

Ogata, H., \& Yano, Y. (2004). Context-aware support for computer-supported ubiquitous learning. In Proceedings of the 2nd IEEE international workshop on wireless and mobile technologies in education (pp. 27-34). Retrieved from

:http://ieeexplore.ieee.org/lpdocs/epic03/wrapper.htm?ar number $1 / 41281330$.

Orey, M. (2002a). Definition of Blended Learning. University of Georgia. Retrieved February 21, 2003, 2003, from the World Wide Web:http://www.arches.uga.edu / mikeorey/blendedLearning 


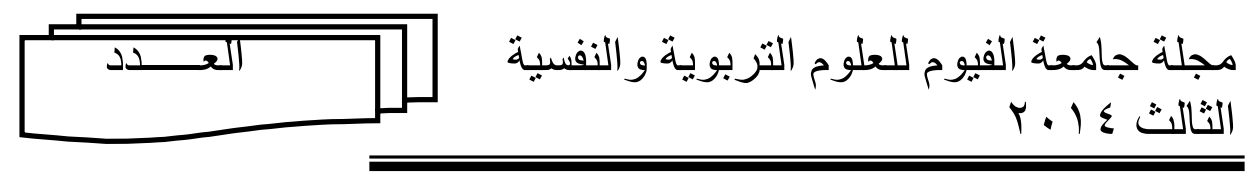

Orey, M. (2002b). One year of online blended learning: Lessons learned. Paper presented at the Annual Meeting of the Eastern Educational Research Association, Sarasota, FL.

Osguthorpe, R. T., \& Graham, C. R. (2003). Blended learning environments: definitions and directions. The Quarterly Review of Distance Education, 4(3), 227-233.

Phipps, R., \&Merisotis, J. (1999). What's the difference? A review of contemporary research on the effectiveness of distance learning in higher education. Washington, DC: The Institute for Higher Education Policy.

Reay, J. (2001). Blended learning - a fusion for the future. Knowledge Management Review, 4(3), 6.

Robertson, J. (2003). So, what is a content management system? KM Column. Retrieved on May 19, 2006 from http://www.steptwo.com.au/papers/kmc_what/pdf/KMC _What.pdf

Rooney, J. E. (2003). Blending learning opportunities to enhance educational programming and meetings. Association Management, 55(5), 26-32.

Rossett, A. (2002). The ASTD E-Learning Handbook: McGrawHill.

Sands, P. (2002). Inside outside, upside downside: Strategies for connecting online and face-to-face instruction in hybrid courses. Teaching with Technology Today, 8(6).

Singh, H., \& Reed, C. (2001). A White Paper: Achieving Success with Blended Learning:Centra Software. 


\section{An analytical view of Students Interaction Ibtesam Al-Nahed Hania Al-Shanawani}

Stacey, E. (1999). Collaborative learning in an online environment. Journal of Distance Education, 14(2), 14-33.

Swan, K. (2001). Virtual interaction: Design factors affecting student satisfaction and perceived learning in asynchronous online courses. Distance Education, 22(2), 306-331.

So. H.J.\& Brush T.A. (2008). Student perceptions of collaborative learning, social presence and satisfaction in a blended learning environment: Relationships and critical factors. Computers \& Education $51,318-336$.

Thomson, I. (2002). Thomson job impact study: The next generation of corporate learning. Thompson, Inc. Retrieved July 7, 2003, from the World Wide Web: http://www.netg.com/DemosAndDownloads/Downloads /JobImpact.pdf

Vesisenaho, M , Valtonen, T. , Kukkonen, J , Havu-Nuutinen, S., Hartikainen, A. (2010) . Blended learning with everyday technologies to activate students' collaborative learning. Science Education International ,Vol.21, No.4, 272-283.

Ward, J., \& LaBranche, G. A. (2003). Blended learning: The convergence of e-learning and meetings. Franchising World, 35(4), 22-23.

Yengina ,1., Karahocab ,D. , Karahocab. A.\& Yücelb .A (2010) Roles of teachers in e-learning: How to engage students $\&$ how to get free e-learning and the future. Procedia Social and Behavioral Sciences 2 , 5775-5787. 


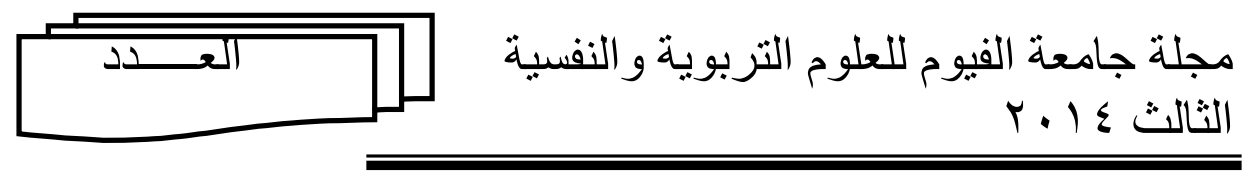

Young, J. R. (2002, March 22). 'Hybrid' teaching seeks to end the divide between traditional and online instruction. Chronicle of Higher Education, pp. A33.

YUCEL, A.S. (2006). E-LEARNING APPROACH IN TEACHER TRAINING Turkish Online Journal of Distance Education- V: 7 / 4 Article: 11

Yushau, B. 2006. The effects of blended e-learning on mathematics and computer attitudes in pre-calculus algebra. The Montana Mathematics Enthusiast 3, no. 2: 176-83.

Zhang, D.; Zhou L. Briggs R.O. ; Nunamaker J.F. (2006). Instructional video in e-learning: Assessing the impact of interactive video on learning effectiveness. Information \& Management , 43, 15-27.

Zhu.C. (2011). Online collaborative learning: Cultural differences in student satisfaction and performance. Journal for Educational Research Online. Volume 3 No. 1, 12-28.

Zhu, C. (2012). Student Satisfaction, Performance, and Knowledge Construction in Online Collaborative Learning. Educational Technology \& Society, 15 (1), 127-136. 


\section{Appendices \\ Appendix (A) \\ Face-to-face interview with ss' responses}

Face-to-Face Interview

Students were asked to participate in face-to-face interviews. Each interview took approximately 50-60 min. The interview questions were open-ended to allow the researcher to explore issues raised by the participants.

There are three types of interaction:

(a) learner-content interaction, (b) learner-instructor interaction, and (c) learner-learner interaction. The interaction between learner and content takes place when learners gain content knowledge through one or more forms of media such as tutorials, CD-ROMs, or web-based courses. The learner instructor interaction happens when an instructor delivers content knowledge, provides appropriate scaffolding, clarifies misunderstanding, and increases student motivation. Lastly, the learner-learner interaction occurs when learners in different geographical areas interact with each other to achieve a certain goal.

Some of the questions included:

1. What were the major differences of collaboration with classmates between traditional and distance courses? 
- Way of communicating assignments, receiving marks, browsing content all are easier than using the traditional method.

- Traditional courses are better for communication and comprehension

- Communication is faster in the blackboard system.

- Cooperation and communication with classmates are faster in the blackboard system

- Communication with instructors is better

2. How important was collaboration with classmates to your satisfaction with this course?

- Cooperation and communication are limited to assignments and sending lecture content.

- Communication with classmates in the same branch only is easy

- Communication and cooperation are not continuous

- Getting any announcements concerning tests or sending others to all students at the same time

- Self -responsibility

3. What would have improved your collaboration with classmates?

- Getting help during group collaboration and presentations

- Collaborative learning is better in the blackboard system.

- Blackboard system gives instructors main important role in supporting and encouraging collaborative learning. 


\section{An analytical view of Students Interaction Ibtesam Al-Nahed Hania Al-Shanawani}

- Most students agree that there is not clear and continuous collaboration in the blackboard environment.

- Getting information from peers is easy.

4. What are technical problems that students face while using e-learning environment?

- Opening the page is very slow.

- Changing the browser

- Load on the net that affects the site negatively

- The process of signing in .

- The system does not work on all systems or sets

- Problems in maintenance.

5. What are technical problems that students face while using e-learning environment at home?

- No technical support outside work hours . students cannot overcome technical problems at home.

6. Express your opinion whether you prefer using elearning environment (Black board) or the traditional face to face interaction?

- The blackboard environment is better in sending assignments and single communication with teachers .

- It saves time and effort.

- It saves money of printing and using papers.

- It does not give immediate feedback

- Face to face communication is very important because of the process of face to face interaction and $\mathrm{c}$ communication. 


\section{الع}

مجلة جامعة الفيوم للعلوم التربوية و النفسية

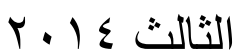

- Students' absence does not represent difficulty in getting the content easily.

- Blackboard is exciting, interesting and varied more the traditional one.

7. What are positive sides of using e-learning environment?

- Students' names in the branch are available, this availability facilitates communication between instructor and students.

- Self-responsibility,

- Load is on the students in the e-learning environment

- Content is available .

- Students are sure that instructors got the assignments.

- The system is clear and easy to use.

- Use everywhere

- Saving time and effort

- To cope with civilized development.

8. What do you suggest to facilitate using e-learning environment?

- Decreasing steps of the program

- Training on using the program

- Using the program in all or most courses

- Solving technical problems.

- No deadline for sending assignments

- Helping students solve technical problems themselves 
9. What do you want to change in the system?

- $90 \%$ of students said, nothing except developing services and re-organizing the site.

10. What do you want to fix in the system?

- Messages to communicate with students anytime after ending the course .

- Content for study.

11.Did e-learning environment have a role in your academic achievement?

- Yes, to cope with civilized development

- Getting to know new technological issues that serve education and learning.

- Using videos to facilitate communicating information.

- Browsing different sites to get information that help doing assignments.

- Making use of the system to download assignment in different courses.

- Writing assignments in a scientific way using accurate language.

12.How do you evaluate your interaction with e-learning, $1-10$ ?

3-7 for most students 


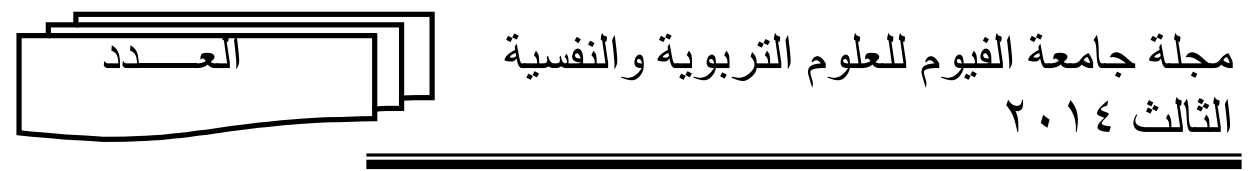

Appendix (B)

The Collaborative Learning and Satisfaction

Questionnaire(CLS).

\title{
Analytical view of students interaction with e- learning environment (Blackboard) at King Saud University
}

Prepared by

Ibtesam Alnahed

Hania Alshanawany

\author{
Supervisor \\ Dr. Noura Alhazzany \\ Second term (1432 - 1433 H. $)$
}




\section{An analytical view of Students Interaction Ibtesam Al-Nahed Hania Al-Shanawani}

Dear student,

The researchers are conducting a research entitled " Analytical view of students interaction with elearning environment (Blackboard) at King Saud University" as one of the Ph.D. requirements.

Due to the importance of your cooperation and participation in the research, Please answer the questions objectively and accurately.

The questionnaire originally consisted of five sections and 38 items . It was developed to measure students levels of collaborative learning, satisfaction, attitudes towards elearning and the effect of students use of e-learning on their learning styles.

Section 1 (general information): four demographic items

Section 2 (Attitudes scale): it consists14 items divided into two parts:

- Students' attitudes towards e-learning environment (6 items).

- Effect of students' use of e- learning on their learning style(8 items).

Section 3( satisfaction scale) : it consisted of sentences that measure students' satisfaction with e-learning environment. 


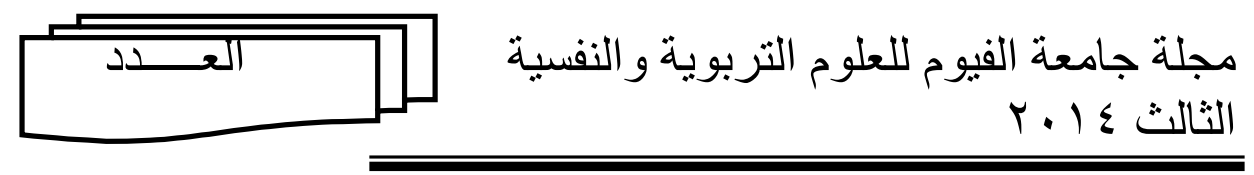

Section 4 (Collaborative learning scale): 13 items were constructed to measure students' perspectives on preferences to group versus individual work and preferences to online interaction versus face to face interaction, amount of collaboration and overall satisfaction with collaborative learning.

\section{a. Blended Learning:}

So and Brush (2008) defined blended learning as any combination of learning delivery methods, including most often face-to-face instruction with asynchronous and/or synchronous computer technologies.

\section{b. interaction:}

Interaction can be defined as a reciprocal communication process between human and human or between human and non-human (e.g., human-computer interaction) ( So and Brush,2008).

\section{c. Satisfaction:}

An affective learning outcome indicating the degree of: (a) learner reaction to values and quality of learning, and (b) motivation for learning ( So and Brush,2008).

The researcher will adopt So \& Brush (2008)'s definition. 


\section{d.E-Learning:}

A learning situation where instructors and learners are separated by distance, time, or both. E-learning uses network technologies to create, foster, deliver, and facilitate learning, anytime and anywhere (Raab, Ellis, \& Abdon, 2002)... The researcher will adopt this definition.

\section{e. Collaborative learning:}

An instructional approach in which a small number of learners interact together and share their knowledge and skills in order to reach a specific learning goal ( So and Brush,2008).

Your information will be dealt with confidentially .

Thank you for your cooperation

The researchers: Ibtesam Alnahed and Hania Alshanawany

\section{Demographic details:}

Check the details that apply to you:

1. Academic Level:

First

$\bigcirc$ Second

$\bigcirc$ Third

$\bigcirc$ Fourth

$\bigcirc$ Fifth

Sixth 


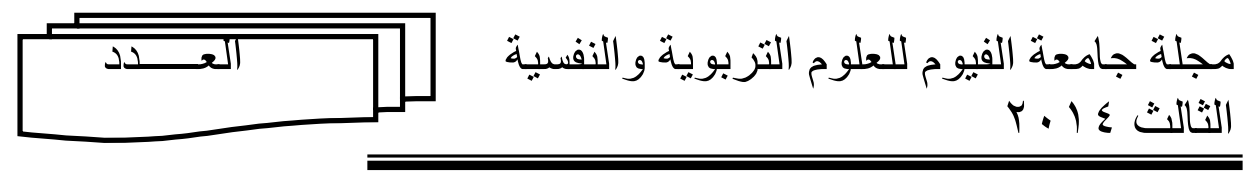

\section{Specialization:}

Education and Early Childhood Education

$\bigcirc$ Special Education

Other

\section{Your level in computer experience}

\begin{tabular}{|c|c|}
\hline & No experience \\
\hline & Beginner \\
\hline & Intermediate \\
\hline & Expert \\
\hline
\end{tabular}

4. Number previous of e-learning courses :circle the correct number:

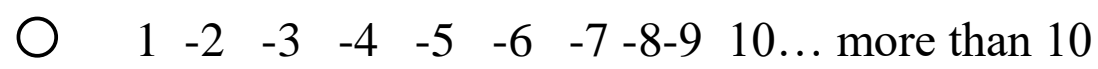

\section{A. Students' attitudes toward e-learning environment and its use as a learning system:}

\begin{tabular}{|l|l|l|l|l|l|l|}
\hline $\mathbf{N}$ & Item & $\begin{array}{l}\text { Strongl } \\
\text { y agree }\end{array}$ & Agree & unsure & $\begin{array}{l}\text { Not } \\
\text { agree }\end{array}$ & $\begin{array}{l}\text { Strongl } \\
\mathbf{y o t} \\
\text { agree }\end{array}$ \\
\hline $\mathbf{1}$ & $\begin{array}{l}\text { Using technological learning } \\
\text { systems are among the } \\
\text { necessary proficiencies }\end{array}$ & & & & & \\
\hline $\mathbf{2}$ & $\begin{array}{l}\text { Using modern technology in } \\
\text { learning is supported by } \\
\text { teachers }\end{array}$ & & & & & \\
\hline $\mathbf{3}$ & $\begin{array}{l}\text { Using modern technology } \\
\text { replaces traditional learning } \\
\text { systems }\end{array}$ & & & & & \\
\hline
\end{tabular}




\section{An analytical view of Students Interaction Ibtesam Al-Nahed Hania Al-Shanawani}

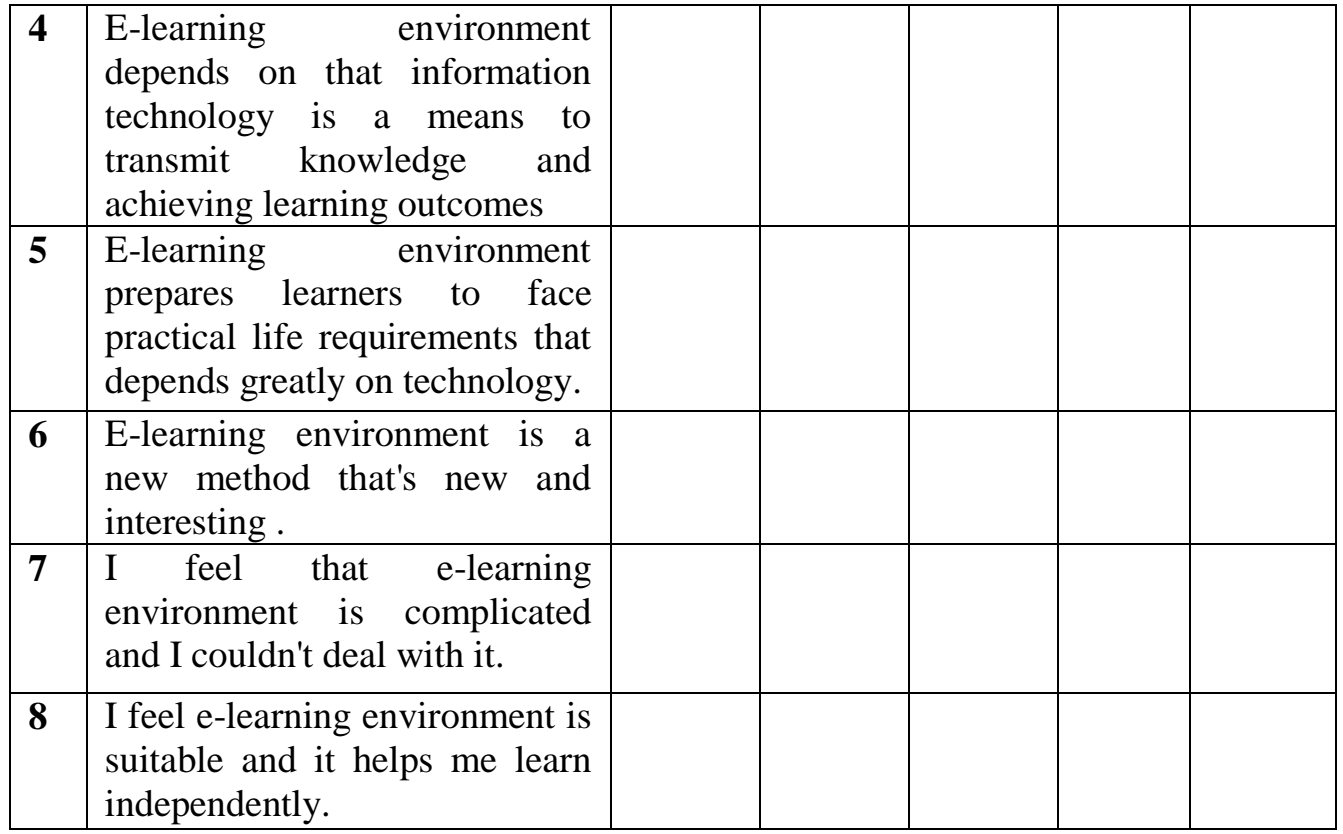

\section{B. Students' use of e - learning and its effect on their learning}

styles:

\begin{tabular}{|c|c|c|c|c|c|c|}
\hline $\mathbf{N}$ & Item & $\begin{array}{l}\text { Strongly } \\
\text { agree }\end{array}$ & disagree & unsure & $\begin{array}{l}\text { Agree } \\
\text { strongly }\end{array}$ & $\begin{array}{l}\text { not } \\
\text { agree }\end{array}$ \\
\hline 1 & $\begin{array}{l}\text { E-learning environment } \\
\text { is characterized by ease } \\
\text { of use and saving } \\
\text { labour. }\end{array}$ & & & & & \\
\hline 2 & $\begin{array}{l}\text { E-learning environment } \\
\text { helps in managing time }\end{array}$ & & & & & \\
\hline 3 & $\begin{array}{lr}\text { Using } & \text { e-learning } \\
\text { environment as a } \\
\text { learning system affects } \\
\text { individual interaction } \\
\text { with } \\
\text { positively(social others } \\
\text { intelligence) }\end{array}$ & & & & & \\
\hline 4 & $\begin{array}{lr}\text { E-learning } & \text { environment } \\
\text { gives } & \text { immediate } \\
\text { feedback } & \end{array}$ & & & & & \\
\hline
\end{tabular}




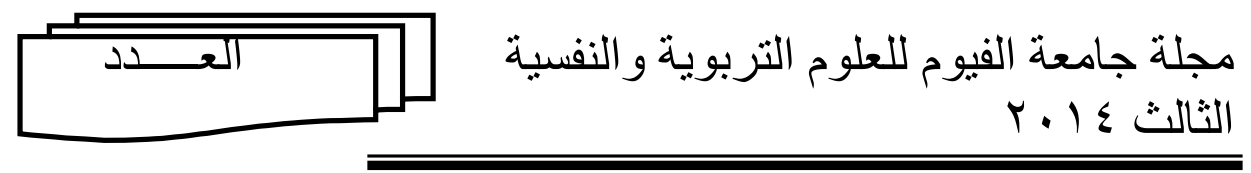

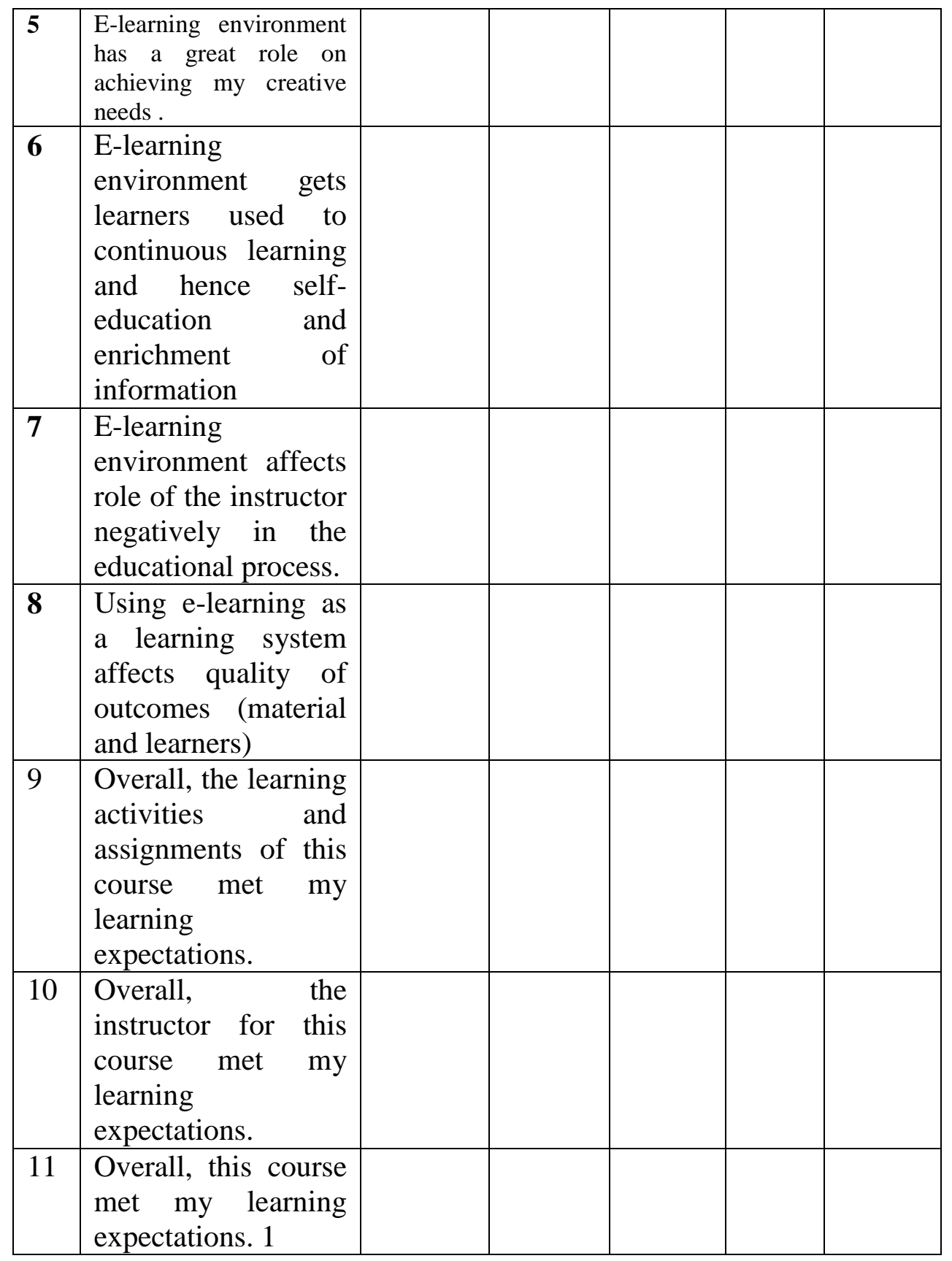




\section{An analytical view of Students Interaction Ibtesam Al-Nahed Hania Al-Shanawani}

\section{Students' satisfaction with e-learning environment:}

\begin{tabular}{|c|c|c|c|c|c|c|}
\hline $\mathbf{n}$ & Item & $\begin{array}{l}\text { Strongly } \\
\text { Disagree }\end{array}$ & Disagree & unsure & $\begin{array}{c}\text { Agree } \\
\text { Strongly }\end{array}$ & Agree \\
\hline 1 & $\begin{array}{l}\text { I was able to learn from On } \\
\text { course discussions }\end{array}$ & & & & & \\
\hline 2 & $\begin{array}{l}\text { I was stimulated to do } \\
\text { additional readings or research } \\
\text { on topics discussed in On } \\
\text { course. }\end{array}$ & & & & & \\
\hline 3 & $\begin{array}{l}\text { Discussions assisted me in } \\
\text { understanding other points } \\
\text { of view. }\end{array}$ & & & & & \\
\hline 4 & $\begin{array}{l}\text { As a result of my experience } \\
\text { with this course, I would } \\
\text { like to take another distance } \\
\text { course in the future. }\end{array}$ & & & & & \\
\hline 5 & $\begin{array}{l}\text { This course was a useful } \\
\text { learning experience. }\end{array}$ & & & & & \\
\hline 6 & $\begin{array}{l}\text { The diversity of topics in } \\
\text { this course prompted me to } \\
\text { participate in the } \\
\text { discussions. }\end{array}$ & & & & & \\
\hline 7 & $\begin{array}{l}\text { I put in a great deal of effort } \\
\text { to learn the Computer - } \\
\text { mediated communication } \\
\text { system to participate in this } \\
\text { course. }\end{array}$ & & & & & \\
\hline 8 & $\begin{array}{l}\text { My level of learning that } \\
\text { took place in this course } \\
\text { was of the highest quality. }\end{array}$ & & & & & \\
\hline
\end{tabular}




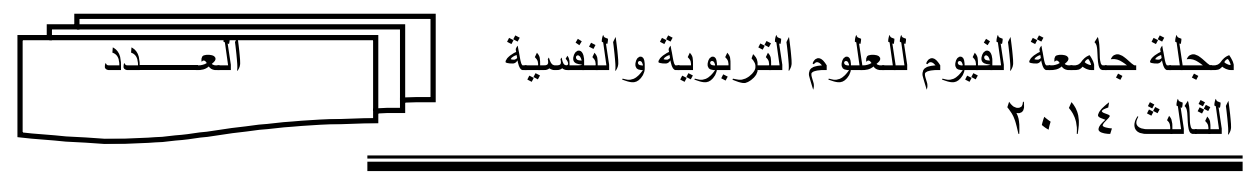

\section{Collaborative learning scale :}

\begin{tabular}{|c|c|c|c|c|c|}
\hline $\mathrm{n}$ & item & $\begin{array}{l}\text { Strongly } \\
\text { Disagree }\end{array}$ & Disagree & unsure & $\begin{array}{l}\text { Agree } \\
\text { Strongly }\end{array}$ \\
\hline 1 & $\begin{array}{l}\text { Collaborative learning experience in } \\
\text { the computer mediated } \\
\text { communication environment is better } \\
\text { than in } \\
\text { a face-to-face learning environment }\end{array}$ & & & & \\
\hline 2 & $\begin{array}{l}\text { I felt part of a learning community in } \\
\text { my group. }\end{array}$ & & & & \\
\hline 3 & $\begin{array}{l}\text { I actively exchanged my ideas with } \\
\text { group members }\end{array}$ & & & & \\
\hline 4 & $\begin{array}{l}\text { I was able to develop new skills and } \\
\text { knowledge from other members in } \\
\text { my group. }\end{array}$ & & & & \\
\hline 5 & 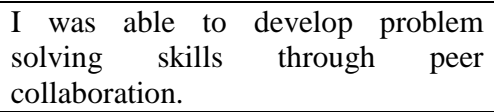 & & & & \\
\hline 6 & $\begin{array}{l}\text { Collaborative learning in my group } \\
\text { was effective. }\end{array}$ & & & & \\
\hline 7 & $\begin{array}{l}\text { Collaborative learning in my group } \\
\text { was time -consuming. }\end{array}$ & & & & \\
\hline 8 & $\begin{array}{l}\text { Overall, I am satisfied with my } \\
\text { collaborative learning experience in } \\
\text { this course. }\end{array}$ & & & & \\
\hline 9 & $\begin{array}{l}\text { Communication in e-learning } \\
\text { environment helps me establishing } \\
\text { relations based on sharing and } \\
\text { exchanging information. }\end{array}$ & & & & \\
\hline 10 & 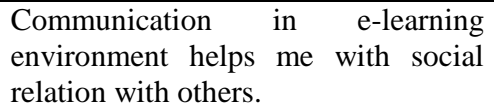 & & & & \\
\hline 11 & $\begin{array}{l}\text { I feel comfortable during participation } \\
\text { although I don't know the nature of } \\
\text { subjects }\end{array}$ & & & & \\
\hline 12 & $\begin{array}{ll}\text { It's easy to express what } & \text { I want to } \\
\text { communicate in } & \text { e-learning } \\
\text { environment } & \end{array}$ & & & & \\
\hline 13 & $\begin{array}{l}\text { Using communication in e0learning } \\
\text { environment is an interesting way to } \\
\text { communicate with others. }\end{array}$ & & & & \\
\hline
\end{tabular}




\section{Appendix (C)}

$$
\text { استبانة عن }
$$

نظرة تحليلية لتفاعل الطالبات مع بيئة التعلم الإكتروني (بلاك بورد) في جامعة

$$
\text { الملك سعود }
$$

Analytical view of students interaction with e-

learning environment (Blackboard) at King Saud University

$$
\begin{aligned}
& \text { إعـــداد: }
\end{aligned}
$$

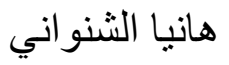

$$
\begin{aligned}
& \text { ابتسام الناهض } \\
& \text { إشـــــــ }
\end{aligned}
$$

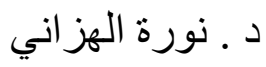

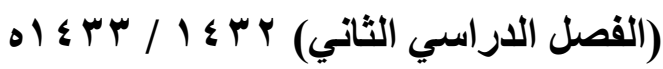




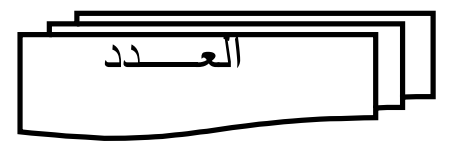

مجلة جامعة الفيوم للعلوم التربوية و النفسية

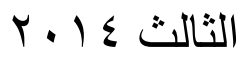

حفظلك الله

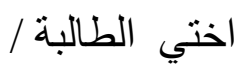

السلام عليكم ورحمة الله وبركاته وبعد..

تقوم الباحثة بدر اسة ميدانية بعنوان (نظرة تحليلية لتفاعل الطالبات مع بيئة التعلم الإكتروني (بلاك بورد) في جامعة الملك سعود) , وذلك كأحد متطلبات مواد

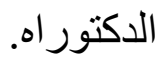

ونظراً لأهمية مشاركتكن وما عهدناه من تعاونكن، أرجو التكرم بالإجابة عن

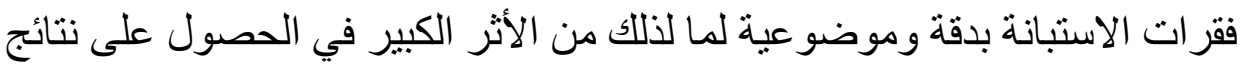
صحيحة. علماً بأن الاستبانة مكونة من أربعة محاور رئيسية : الأول ويشمل معلومات عامة ويضم ؟ بنود ديموغر افية.

و الثاني مقياس ويتكون من شقين الأول ، استخدام بيئة التعلم الإلكتروني (بلاك

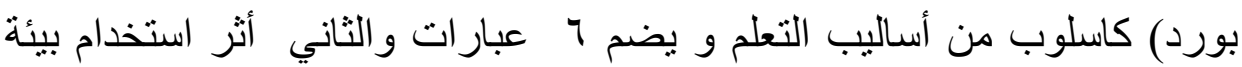

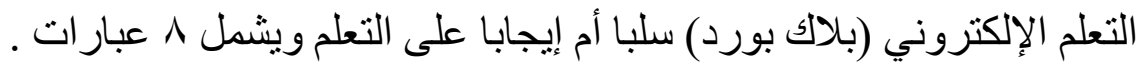

و الثالث مقياس رضا الطالبات على بيئة التعلم الإلكتروني (بلاك بورد) ويشمل 1 ( إبارة تتعلق بثلاثة محاور عن البرنامج الدارسي و المعلم والأنثطة التعليمية . و الر ابع مقياس التعلم التعاوني و التفاعل في بيئة التعلم الإلكتروني (بلاك بورد) و يضمب ا عن وجهات نظر الطلاب حول تفضيل العمل الجماعي استخدام بيئة التعلم الإلكتروني (بلاك بورد) مقابل العمل الفردي .

وجهات نظر الطلاب حول تفضيلات التفاعل عبر استخدام بيئة التعلم الإلكتروني

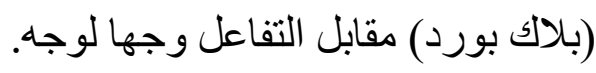

وجهات نظر الطلاب حول مقدار التعاون والرضا الكلي عن التعلم التعاوني في بيئة التعلم الإلكتروني (بلاك بورد). 


\section{An analytical view of Students Interaction Ibtesam Al-Nahed Hania Al-Shanawani}

التعلم التعاوني: منهج تعليمي يتفاعل فيه عدد صغير من الدارسين مع بعضهم

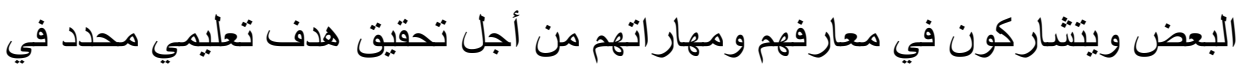

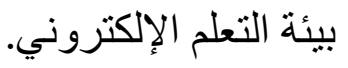
الرضا: رضا الطالبات عن ممارسة التعلم في بيئة التعلم الإلكتروني. بيئة التعلم الإكترّوني ( بلاك بورد ) يقصد به التعلّم الذي يخلط بين خصائص كل

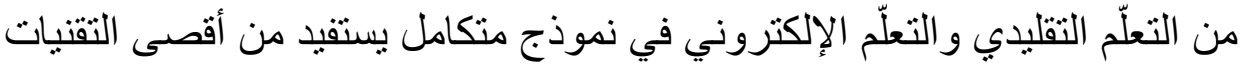

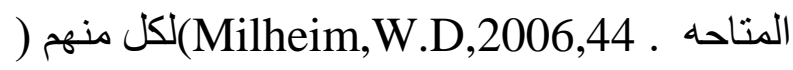
مع العلم أن جميع المعلومات الواردة في الاستبانة ستستخدم لأغراض البحث العلمي فقط, وسوف تحظى بسرية تامة. شاكره لسعادتكن حسن تعاونكن الباحثات ، ابتسام الناهض و هانيا الثنو اني. أولاً: البيانات الأولية: ضعي علامة صح أمام العبارة التي تنطبق عليك ـ ـ المستوى الدر اسي حسب الخطة :

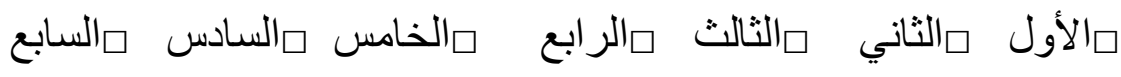

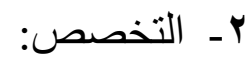

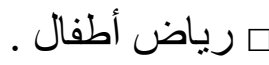

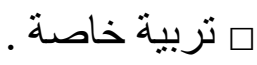

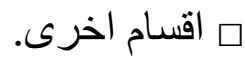
r- يرجى تقدير مستو الك في خبرتك بالحاسب الآلي

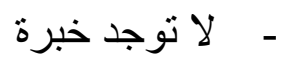




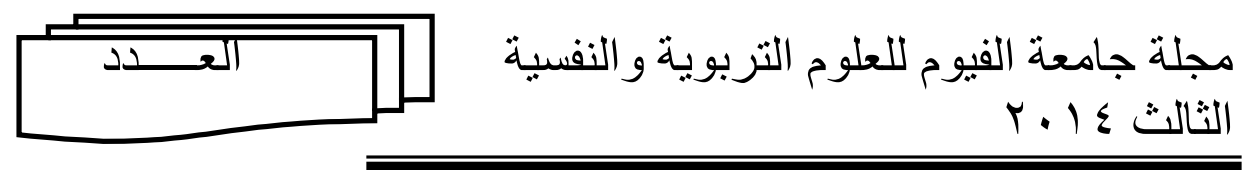

$$
\text { - - مبتدى - متوسط }
$$

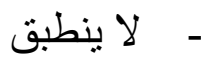

عـ كم عدد المقررات التي تستخدم بيئة التعلم الإلكتروني درستيها حتى الآن؟ يرجى وضع دائرة حول العدد.

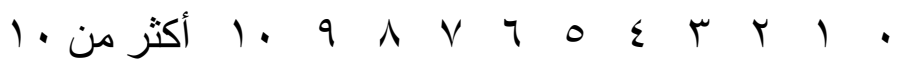




\begin{tabular}{|c|c|c|c|c|c|c|}
\hline بشوافق بير & غوافق & 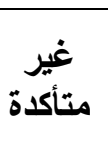 & أوافق & 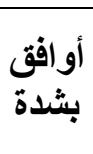 & الــــــعبــــــــــارة & s \\
\hline & \multicolumn{6}{|c|}{ ثنانيا :أــ اتجاه الطالبات نحو بيئة التعلم الإلكتروني (بلاكك بورد) واستخدامه كأسلوب } \\
\hline & & & & & 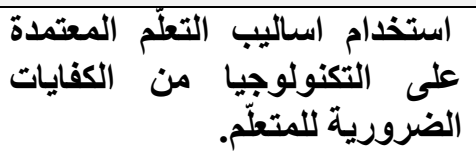 & 1 \\
\hline & & & & & 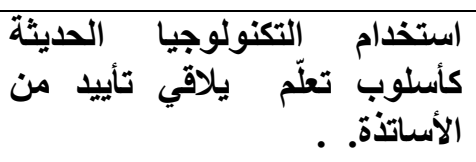 & r \\
\hline & & & & & 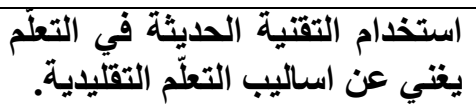 & $r$ \\
\hline & & & & & 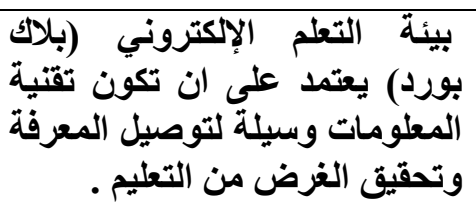 & $\varepsilon$ \\
\hline & & & & & 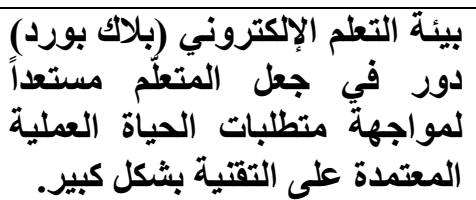 & 0 \\
\hline & & & & & أشلئة التعلم الإكتروني (بلاكت بورد) & 7 \\
\hline
\end{tabular}




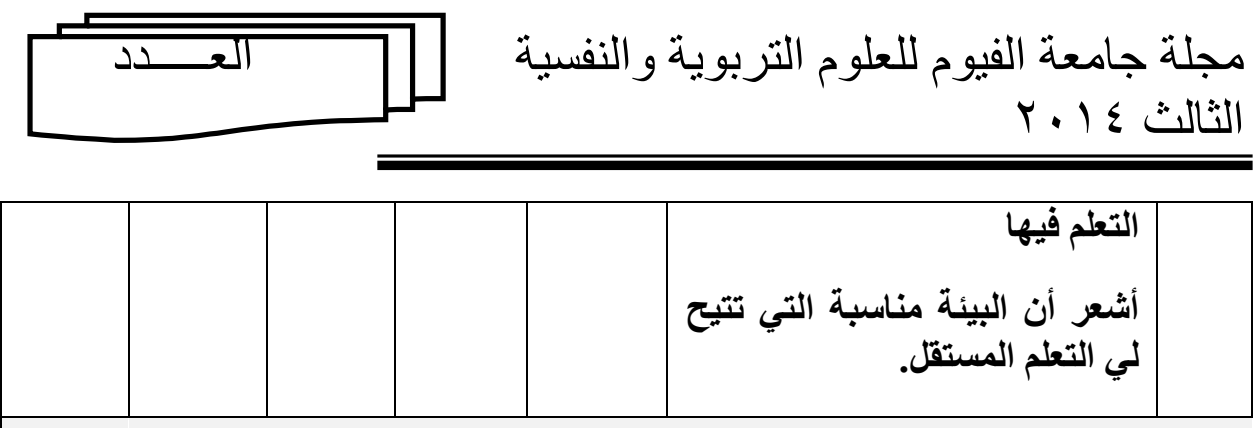

ب - تأثثير استخدام الطالبات بيئة التعلم الإكتروني (بلاك بورد) وتأثيرها على اساليب تعلمهن سلباً و إيجاباً:

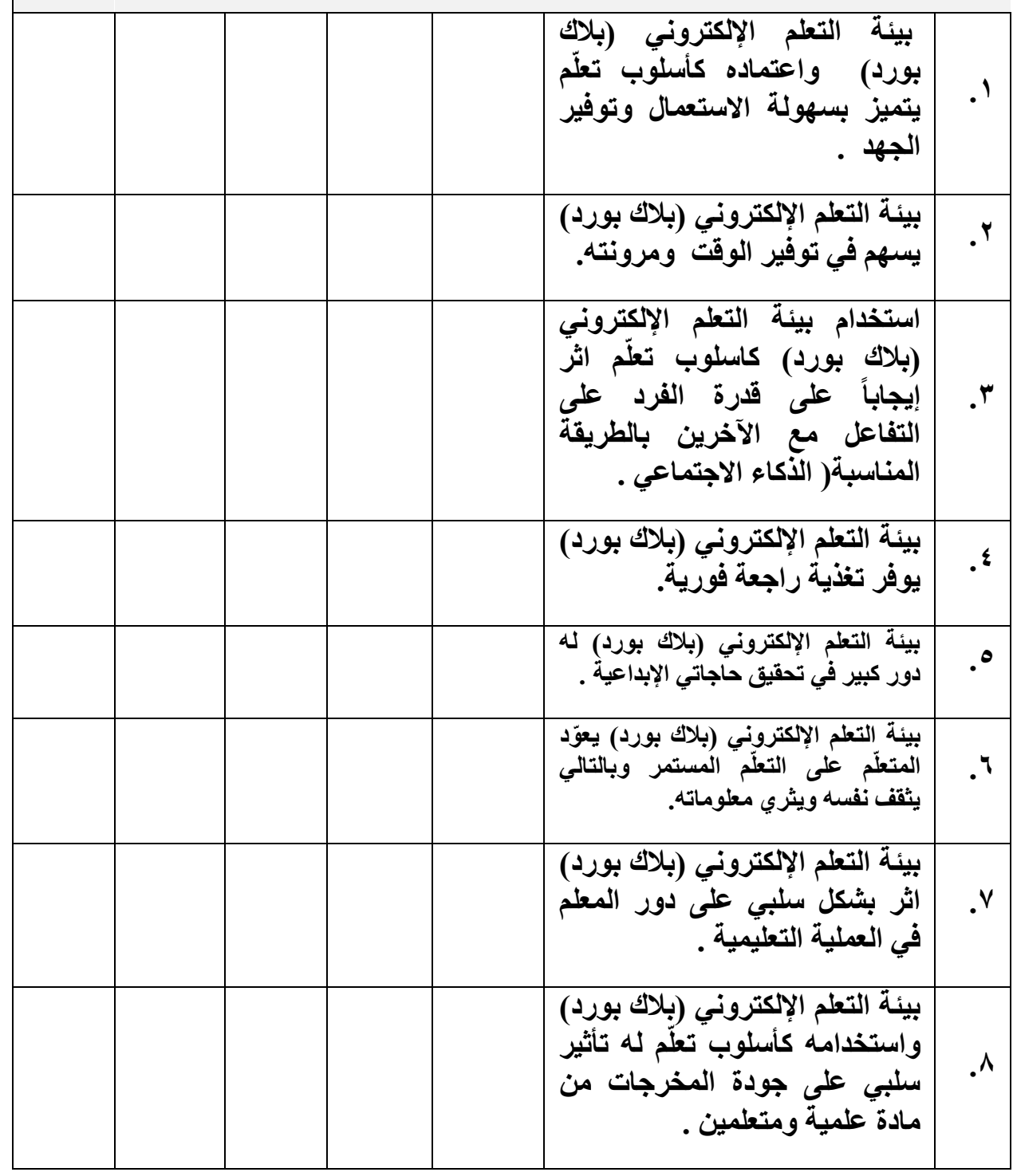




\section{An analytical view of Students Interaction Ibtesam Al-Nahed Hania Al-Shanawani}

\begin{tabular}{|c|c|c|c|c|c|}
\hline بثوافئ & غئق & 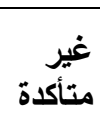 & 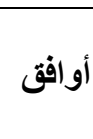 & بثدة أفق & 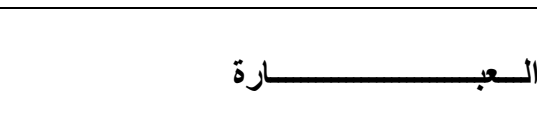 \\
\hline \multicolumn{6}{|c|}{ قالثا : مقياس الرضا ويتضمن عبارات تقيس الرضا عن البرنامج الاراسي والأنثطة التُعليمية . } \\
\hline & & & & & 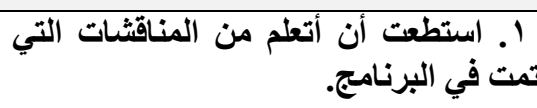 \\
\hline & & & & & 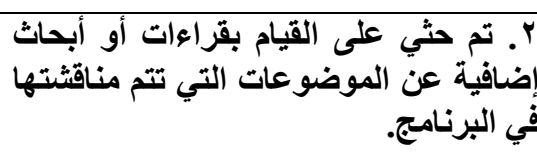 \\
\hline & & & & & وجهات نظظر أخرى . \\
\hline & & & & & 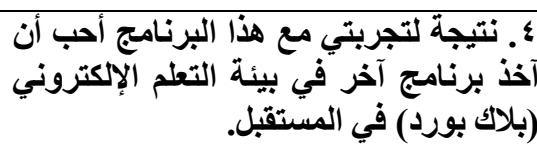 \\
\hline & & & & & ๑. هذا البرنامج كان تجربة تعليمية مفيدة. \\
\hline & & & & & لَج. تنوعى على المشاركة في المناقشنات. البرنامج \\
\hline & & & & & 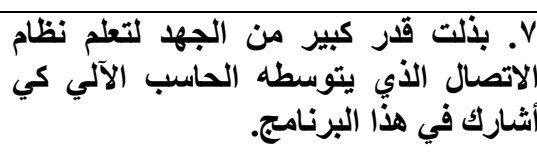 \\
\hline & & & & & ^البرنامج كستوى ذو جوديمي فائقة. حلث في هذا \\
\hline & & & & & 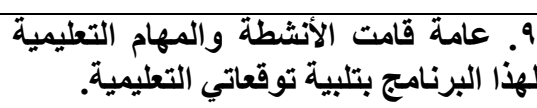 \\
\hline & & & & & 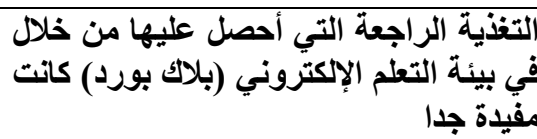 \\
\hline
\end{tabular}




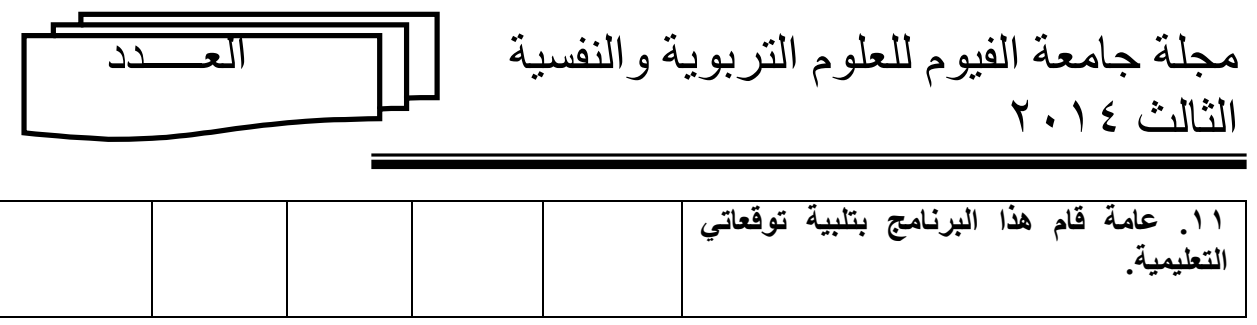

\begin{tabular}{|c|c|c|c|c|c|}
\hline 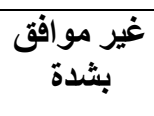 & موافيق & 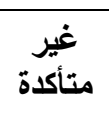 & 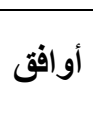 & 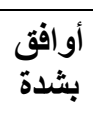 & الــــعبـــــــرة \\
\hline \multicolumn{6}{|c|}{ رابعا : مقياس التعلم التعاوني و التفاعل في بيئة التعلم الإكتروني (بلاك بورد) . } \\
\hline & & & & & 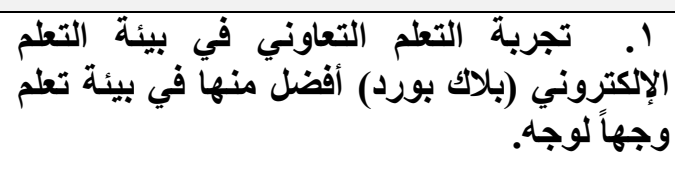 \\
\hline & & & & & r. ش. شعرت أني جزء من المجتمع التعليمي في مجموعتي. \\
\hline & & & & & rا ل لقد تبادلت أفكاري مع أعضاء المجموعة. \\
\hline & & & & & أعضاء آختطعت تبالمجموعة مهارات ومعارف جديدة من \\
\hline & & & & & التعاون مع الزميلات تطوير مهارات حل المشاكل عن طريق \\
\hline & & & & & \َ. التعلم التعاوني في مجموعتي كان فعالاً. \\
\hline & & & & & V. التعلم التعاوني في مجموعتي كان مهرراً للوقت. \\
\hline & & & & & 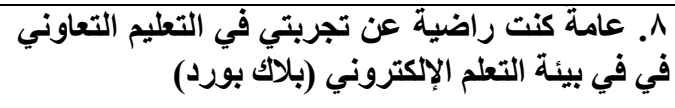 \\
\hline & & & & & 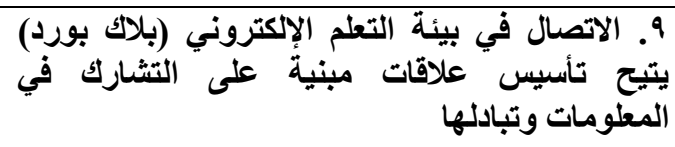 \\
\hline & & & & & 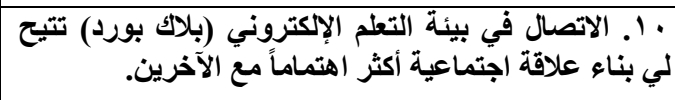 \\
\hline & & & & & لست على علم بالموضة عند المشاركة بالر غم من أنتي \\
\hline & & & & & 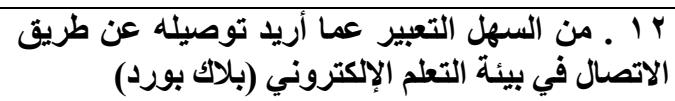 \\
\hline
\end{tabular}


An analytical view of Students Interaction Ibtesam Al-Nahed Hania Al-Shanawani

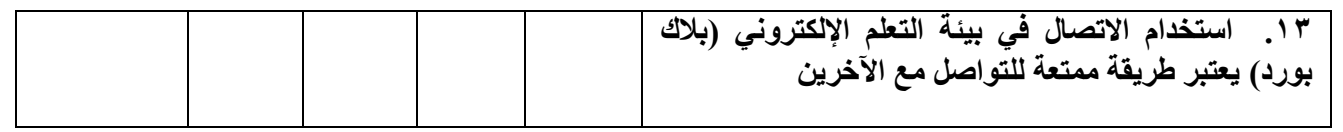

